\title{
Formation and Crystal Structures of Lewis Acid Adducts of Ph3PCHP(O)Ph2; New Neutral and Cationic Species
}

\begin{tabular}{|r|l|}
\hline Journal: & Zeitschrift für Anorganische und Allgemeine Chemie \\
\hline Manuscript ID: & zaac. 201000092.R1 \\
\hline Wiley - Manuscript type: & Article \\
\hline Date Submitted by the & 08-Mar-2010 \\
\hline Complete List of Authors: & $\begin{array}{l}\text { Petz, Wolfgang; Universität Marburg } \\
\text { Neumüller, Bernhard } \\
\text { Aicher, Kathrin } \\
\text { Öxler, Florian }\end{array}$ \\
\hline Keywords: & $\begin{array}{l}\text { carbodiphosphorane, hydrolysis product, Lewis acid adducts, crystal } \\
\text { structures }\end{array}$ \\
\hline
\end{tabular}

\section{S ScholaroNE \\ Manuscript Central}




\title{
Formation and Crystal Structures of Lewis Acid Adducts of $\mathrm{Ph}_{3} \mathrm{PCHP}(\mathrm{O}) \mathrm{Ph}_{2}$; New Neutral and Cationic Species
}

\author{
Wolfgang Petz, ${ }^{*[a]}$ Florian Öxler, Kathrin Aicher, and Bernhard Neumüller ${ }^{*}[\mathrm{a}]$
}

Dedicated to Professor Bernd Harbrecht on the Occasion of his $60^{\text {th }}$ Birthday

Prof. Dr. Wolfgang Petz

E-mail: petz@ staff.uni-marburg.de

* Prof. Dr. Bernhard Neumüller

E-Mail: neumuell@chemie.uni-marburg.de

Fax: int.-6421/2825653

[a] Fachbereich Chemie der Philipps-Universität

Hans-Meerwein-Strasse

35032 Marburg, Germany 
Keywords: Carbodiphosphorane; Hydrolysis product; Lewis acid adducts; Crystal structures

\begin{abstract}
The carbodiphosphorane $\mathrm{C}\left(\mathrm{PPh}_{3}\right)_{2}(\mathbf{1})$ is easily hydrolyzed from wet air to give the ylide $\mathrm{Ph}_{3} \mathrm{PCHP}(\mathrm{O}) \mathrm{Ph}_{2}$ (2), which forms addition compounds with various Lewis acids to give neutral or cationic compounds. According to pairs of electrons at the central carbon atom and the oxygen atom, respectively, addition compounds with coordination modes $\mathbf{A}$ (via oxygen), $\mathbf{B}$ (via carbon), and $\mathbf{C}$ (via carbon and oxygen) were isolated either as by-products from reactions of Lewis acids with $\mathbf{1}$ (contaminated with some 2) or directly with $\mathbf{2}$. The crystal structures and the spectroscopic properties of $\mathbf{2}$ and of the addition

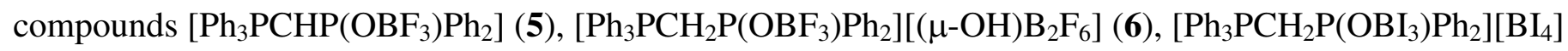
(7), $\left[\mathrm{Ph}_{3} \mathrm{PCHP}\left(\mathrm{OSnCl}_{2}\right) \mathrm{Ph}_{2}\right](\mathbf{8})$, and $\left[\mathrm{Ph}_{3} \mathrm{PCH}_{2} \mathrm{P}(\mathrm{O}) \mathrm{Ph}_{2}\right]_{2}\left[\mathrm{Hg}_{2} \mathrm{I}_{6}\right](\mathbf{9})$ are reported.
\end{abstract}

\title{
1 Introduction
}

The carbodiphosphorane $\mathrm{C}\left(\mathrm{PPh}_{3}\right)_{2}(\mathbf{1})$ and its hydrolysis product $\mathrm{Ph}_{3} \mathrm{PCHP}(\mathrm{O}) \mathrm{Ph}_{2}(\mathbf{2})$ were first described in 1961 by Ramirez et al. [1]. Whereas various addition compounds of $\mathbf{1}$ have been synthesized up to now [2], the chemistry of $\mathbf{2}$ remained unexplored for many years. An earlier reported platinum complex with a side on bounded $\mathrm{C}\left(\mathrm{PPh}_{3}\right)_{2}$ ligand [3] was later identified as pure 2 [4]. 2 can be seen as an ylide derived from the ylide $\mathrm{CH}_{2} \mathrm{PPh}_{3}$ by replacing one proton by the $\mathrm{P}(\mathrm{O}) \mathrm{Ph}_{2}$ group or as a derivative of the phosphane oxide $\mathrm{OPPh}_{3}$ in which one $\mathrm{Ph}$ group is replaced by the ylidic group $\mathrm{CHPPh}_{3}$. To our knowledge, further compounds of the type $\mathrm{Ph}_{3} \mathrm{PCHP}(\mathrm{E}) \mathrm{Ph}_{2}$ with $\mathrm{E}$ other than $\mathrm{O}$ have not been reported so far.

Thus, the chemistry of 2 should be related to both, $\mathrm{CH}_{2} \mathrm{PPh}_{3}$ and $\mathrm{OPPh}_{3}$. In principle, 2 is endowed with two anchor points for Lewis acids (LA), the free pair of electrons at the ylidic carbon atom between the P atoms and a pair of electrons at the oxygen atom. Therefore, 1:1 adducts with $\mathrm{sp}^{2}(\mathbf{A})$ and $\mathrm{sp}^{3}$ carbon atoms $(\mathbf{B})$ or 1:2 adducts with an $\mathrm{sp}^{3}(\mathbf{C})$ carbon atom are expected as depicted in Scheme 1. Coordination modes $\mathbf{A}$ and $\mathbf{B}$ represent hard and soft coordination sites, respectively, of the ylide. In the coordination mode $\mathbf{C}$, the ylide $\mathbf{2}$ can also act as a chelating ligand. In principle, $\mathbf{2}$ is related to the carbonyl-stabilized ylides of the type 
$\mathrm{Ph}_{3} \mathrm{PCHC}(\mathrm{O}) \mathrm{R}$ in which the $\mathrm{P}(\mathrm{O}) \mathrm{Ph}_{2}$ group of 2 is replaced by $\mathrm{C}(\mathrm{O}) \mathrm{R}$ and which exhibits rich coordination chemistry [5].

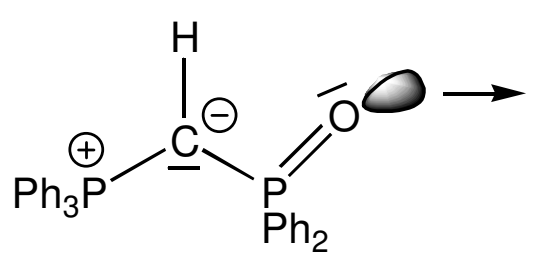

A

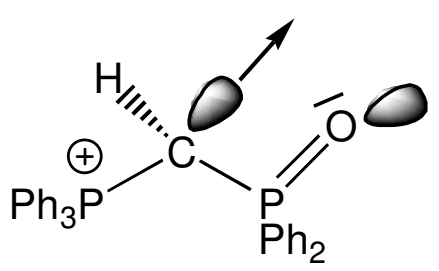

B

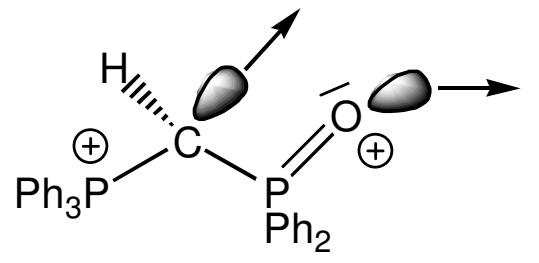

C

Scheme 1. Coordination modes of 2 . The arrows indicate potential donor abilities to Lewis acids.

Reports on the chemistry of $\mathbf{2}$ are rare. The type $\mathbf{A}$ tungsten complex $\left[\mathrm{Ph}_{3} \mathrm{PCHP}\left\{\mathrm{OW}(\mathrm{CO})_{5}\right\} \mathrm{Ph}_{2}\right](\mathbf{3})$ was described in which $\mathbf{2}$ acts as a Lewis base coordinating with the oxygen atom at the electron deficient tungsten carbonyl fragment [6]. The salt like complex $\left[\mathrm{Ph}_{3} \mathrm{PCH}_{2} \mathrm{P}\left(\mathrm{OAlBr}_{3}\right) \mathrm{Ph}_{2}\right]\left[\mathrm{AlBr}_{4}\right](\mathbf{4})$ of the type $\mathbf{C}$ was obtained by us during the preparation of the carbodiphosphorane adduct $\mathrm{Br}_{3} \mathrm{Al} \leftarrow \mathbf{1}$ [7]. Both addition compounds of $\mathbf{2}$ were formed as side-products from reactions of $\mathbf{1}$ with the appropriate Lewis acid. No type B compound has been reported up to now. During our studies with $\mathbf{1}$ as complex ligand, we frequently isolated further derivatives of $\mathbf{2}$ in small amounts. This prompted us to explore the chemistry of $\mathbf{2}$ more intensively in order to find out what pair of electrons is preferred upon using different kinds of Lewis acids. Here we report on the preparation and the crystal structure of $\mathbf{2}$ and on the formation of further adducts of type $\mathbf{A}$ to $\mathbf{C}$ which could be identified and confirmed by X-ray diffraction analyses.

\section{Results and discussion}

Whereas the double ylide $\mathrm{C}\left(\mathrm{PPh}_{3}\right)_{2}(\mathbf{1})$ in the solid state is not very sensitive, solutions readily react with wet air to give 2; and even if reactions with 1 were carried out in dried solvents under argon protection, small amounts of $\mathbf{2}$ are always present as traced by ${ }^{31} \mathrm{P}$ NMR spectroscopy. Thus, $\mathbf{2}$ was obtained in quantitative yields under release of benzene according to equation 1 if a solution of $\mathbf{1}$ in toluene was stirred in contact 
with wet air; the resulting $\mathbf{2}$ is soluble in toluene and can be precipitated by addition of $n$-pentane. However, direct addition of water to $\mathbf{1}$ is not successful; only decomposition products were obtained.

$$
\underset{\mathbf{1}}{\mathrm{C}\left(\mathrm{PPh}_{3}\right)_{2}}+\mathrm{H}_{2} \mathrm{O} \rightarrow \underset{\mathbf{P h}}{\mathrm{Ph}_{3} \mathrm{PCHP}(\mathrm{O}) \mathrm{Ph}_{2}}+\mathrm{C}_{6} \mathrm{H}_{6}
$$

The ${ }^{31} \mathrm{P}$ NMR spectrum of 2 exhibits two characteristic doublets with coupling constants ${ }^{2} \mathrm{~J}(\mathrm{P}, \mathrm{P})=19 \mathrm{~Hz}$ indicating chemically different phosphorus atoms; the low field signal can be attributed to the PO group. A strong solvent dependency of the shifts is observed, and the shift difference $\Delta$ between the doublets range between 4.4 and $7.4 \mathrm{ppm}$, depending on the nature of the solvent. In the IR spectrum the PO stretching vibration cannot be assigned with certainty, because in the region between 1250 and $1100 \mathrm{~cm}^{-1}$ several strong bands were recorded. However, a very strong band at $1171 \mathrm{~cm}^{-1}$ seems to be reliable; the P-O vibration of $\mathrm{Ph}_{3} \mathrm{PO}$ appears at about $1190 \mathrm{~cm}^{-1}[8,9]$.

The majority of compounds based on $\mathbf{2}$ were obtained in small amounts as side-products during our efforts to prepare addition compounds LA $\leftarrow \mathbf{1}$ between the double ylide and various Lewis acids LA, such as compounds of group 13 elements, and attempts to obtain crystals from the crude reaction products. In general, the reactions with $\mathbf{1}$ were carried out in toluene, because the use of halogenated hydrocarbons or

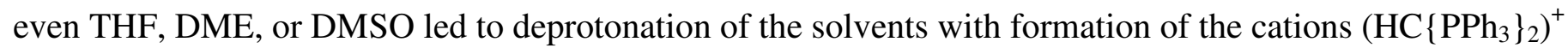
or $\left(\mathrm{H}_{2} \mathrm{C}\left\{\mathrm{PPh}_{3}\right\}_{2}\right)^{2+}$. Unfortunately, the resulting adducts LA $\leftarrow \mathbf{1}$ were insoluble in toluene and other nonpolar solvents, preventing sufficient characterization by NMR and X-ray analyses; however, few crystals were sporadically obtained from freshly prepared filtered toluene solutions. In most cases the precipitates from toluene are soluble in DMSO or halogenated solvents, but the ${ }^{31} \mathrm{P}$ NMR spectra show only the signal of the cation $\left(\mathrm{HC}\left\{\mathrm{PPh}_{3}\right\}_{2}\right)^{+}$, indicating reaction with the solvent with proton abstraction. This is confirmed by IR experiments in which the spectra changed after the precipitates had got contact to polar solvents showing the characteristic medium intense bands of the cation at 1032, 1013, and $991 \mathrm{~cm}^{-1}$. In this contribution we 
concentrate on the discussion of addition products of $\mathbf{2}$ either obtained as side-products by reactions of $\mathbf{1}$ with Lewis acids or upon reaction of $\mathbf{2}$ with Lewis acids, and the results are sketched in Scheme 2.
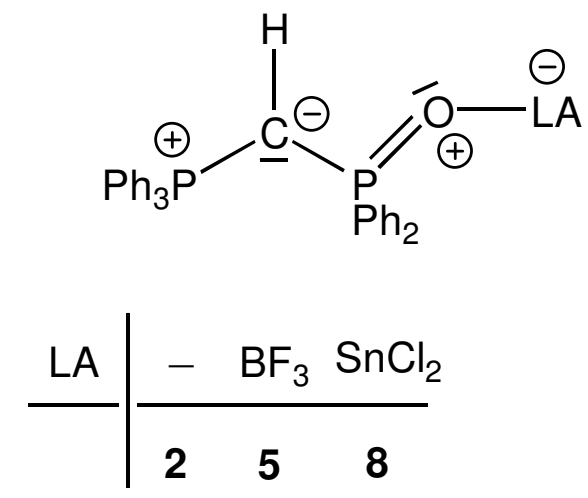
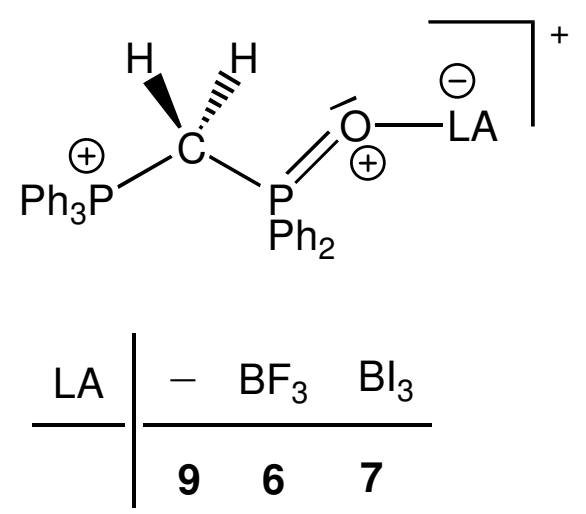

Scheme 2. Compounds of the coordination modes $\mathbf{A}(\mathbf{5}, \mathbf{8}), \mathbf{B}(\mathbf{9})$, and $\mathbf{C}(\mathbf{6}, \mathbf{7})$.

Thus, the type $\mathbf{A}$ compound $\left[\mathrm{Ph}_{3} \mathrm{PCHP}\left(\mathrm{OBF}_{3}\right) \mathrm{Ph}_{2}\right]$ (5) formed when 1, containing small amounts of 2 (as shown by ${ }^{31} \mathrm{P}$ NMR spectroscopy), was allowed to react with gaseous $\mathrm{BF}_{3}$ in toluene; colorless crystals of 5 separated in low yield from the toluene solution, and the desired adduct $\mathrm{F}_{3} \mathrm{~B} \leftarrow \mathbf{1}$ precipitated without forming crystals suitable for an $\mathrm{X}$-ray analysis. Upon coordination of $\mathrm{BF}_{3}$ at the $\mathrm{O}$ atom of $\mathbf{2}$, both doublets experienced a high field shift in the ${ }^{31} \mathrm{P}$ NMR spectrum of $\mathbf{5}$. Attempts to prepare $\mathbf{5}$ directly from $\mathbf{2}$ and $\mathrm{F}_{3} \mathrm{~B} \leftarrow \mathrm{OEt}_{2}$ or $\mathrm{BF}_{3}$ in toluene gave a precipitate which upon recrystallization from $\mathrm{CH}_{2} \mathrm{Cl}_{2} / n$-pentane produced the type $\mathbf{C}$ compound $\left[\mathrm{Ph}_{3} \mathrm{PCH}_{2} \mathrm{P}\left(\mathrm{OBF}_{3}\right) \mathrm{Ph}_{2}\right]\left[(\mu-\mathrm{OH}) \mathrm{B}_{2} \mathrm{~F}_{6}\right](6)$ in good yields; source for the additional proton are the solvent or impurities in $\left[\mathrm{F}_{3} \mathrm{~B}\left(\mathrm{OEt}_{2}\right)\right]$. In the ${ }^{31} \mathrm{P}$ NMR spectrum of 6 a doublet at $17.53 \mathrm{ppm}\left({ }^{2} \mathrm{~J}(\mathrm{P}, \mathrm{P})=17.80 \mathrm{~Hz}\right)$ and a multiplet at $45.63 \mathrm{ppm}$ were measured, which were assigned to $\mathrm{PPh}_{3}$ and $\mathrm{P}\left(\mathrm{OBF}_{3}\right) \mathrm{Ph}_{2}$ phosphorus atoms, respectively. Similarly, from the reaction of 1 with $\mathrm{BI}_{3}$ in toluene the type $\mathbf{C}$ complex $\left[\mathrm{Ph}_{3} \mathrm{PCH}_{2} \mathrm{P}\left(\mathrm{OBI}_{3}\right) \mathrm{Ph}_{2}\right]\left[\mathrm{BI}_{4}\right]$ (7) was obtained as the only crystalline product, and the desired adduct $\mathrm{I}_{3} \mathrm{~B} \leftarrow \mathbf{1}$ could not be identified; instead, only the salt $\left(\mathrm{H}_{2} \mathrm{C}\left\{\mathrm{PPh}_{3}\right\}_{2}\right)\left[\mathrm{I}_{3}\right] \mathrm{I}[10]$ was isolated upon attempts to recrystallize the crude material from acetonitrile. The HI needed for protonation probably 
formed upon borylation and deprotonation of the appropriate solvents. The ${ }^{31} \mathrm{P}$ NMR spectrum of 7 in DCM exhibits a doublet at $16.20 \mathrm{ppm}\left({ }^{2} \mathrm{~J}(\mathrm{P}, \mathrm{P})=20.35 \mathrm{~Hz}\right)$ and a multiplet at $54.55 \mathrm{~Hz}$, according to $\mathrm{PPh}_{3}$ and $\mathrm{P}\left(\mathrm{OBI}_{3}\right) \mathrm{Ph}_{2}$ phosphorus atoms, respectively. Relative to the starting compound 2 , the low field signal has become more deshielded, whereas the high field signal has experienced a high field shift in going to the addition compounds $\mathbf{6}$ and 7. As yet, only type $\mathbf{C}$ compounds were detected in which the Lewis acid at the carbon atom is $\mathrm{H}^{+}$, thus producing salt like compounds. Solvent reactions with proton abstraction of addition compounds with 1 and other Lewis acids were reported recently [11].

If $\mathbf{2}$ was allowed to react with anhydrous $\mathrm{SnCl}_{2}$ in DCM the neutral type $\mathbf{A}$ addition complex $\left[\mathrm{Ph}_{3} \mathrm{PCHP}\left(\mathrm{OSnCl}_{2}\right) \mathrm{Ph}_{2}\right](\mathbf{8})$ could be prepared in high yields and characterized by X-ray analysis. The ${ }^{31} \mathrm{P}$ NMR spectrum of a freshly prepared sample in DCM exhibits two doublets at 38.74, 18.18 ppm (set A) which disappeared within some hours in favor of doublets at 22.96, 21.33 (set $\mathbf{B}$ ). The set $\mathbf{B}$ persisted and was observed as the only signals after isolation of the product indicating the formation of only one type of compounds. The initial signals of set $\mathbf{A}$ apparently belong to an intermediate which could not be identified so far. The IR spectrum of $\mathbf{8}$ exhibits a new strong band at $1018 \mathrm{~cm}^{-1}$ not found in 2 , which can be assigned to the P-OSn vibration.

A quite different reaction pathway was found upon reacting 2 with $\mathrm{HgI}_{2}$ in THF. The clear solution showed a set of two doublets at 21.58 and $20.79 \mathrm{ppm}\left({ }^{2} \mathrm{~J}(\mathrm{P}, \mathrm{P})=14.35 \mathrm{~Hz}\right)$ along with a set of two broad signals at 27.8 and $26.0 \mathrm{ppm}$ in about 1:1 ratio. Attempts to grow crystals gave colorless crystals suitable for X-ray analysis and a pale yellow micro crystalline material which was unsuitable for X-ray analysis. The colorless crystals turned out to be the salt like compound $\left[\mathrm{Ph}_{3} \mathrm{PCH}_{2} \mathrm{P}(\mathrm{O}) \mathrm{Ph}_{2}\right]_{2}\left[\mathrm{Hg}_{2} \mathrm{I}_{6}\right](9)$. The salt can be considered as the first compound of the type $\mathbf{B}$ containing a "free" PO group as in $\mathbf{2}$ but a protonated ylidic carbon atom, thus being its conjugated acid. An alternative pathway, the addition of $\mathrm{HgCl}_{2}$ at the carbon atom, as expected, could not be found. However, the formation of such kind of adduct as intermediate can neither be excluded nor be established; no other type of crystals was found. It could be responsible for the unusual 
deprotonation of the solvent. The IR spectrum of 9 exhibits a strong band at $1184 \mathrm{~cm}^{-1}$, which probably can be assigned to the P-O vibration.

\section{Crystal structures}

For comparison and for documentation of the changes in the parameters upon adduct formation we have also studied the crystal structure of $\mathbf{2}$; colorless crystals separated from a toluene solution after layering with $n$ pentane. Crystals of $\mathbf{5}$ (adduct of the type $\mathbf{A}$ ) were obtained as described above. The related $\mathrm{H}\left[\mathrm{HOB}_{2} \mathrm{~F}_{6}\right]$ adduct 6 was obtained from the reaction of 2 with $\left[\mathrm{F}_{3} \mathrm{~B}\left(\mathrm{OEt}_{2}\right)\right]$, and crystals of $7 \cdot \mathrm{C}_{7} \mathrm{H}_{8}$ formed from a toluene solution; the adducts are of the type $\mathbf{C}$. Additionally, we have obtained crystals of the type $\mathbf{A}$

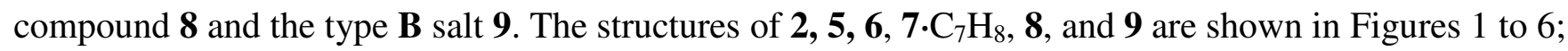
crystallographic data are collected in Table 1; bond lengths and angles are summarized in Tables 2 to 7.

\subsection{Crystal structure of $\mathrm{Ph}_{3} \mathrm{PCHP}(\mathrm{O}) \mathrm{Ph}_{2}(2)$}

The unit cell of $\mathbf{2}$ contains two independent molecules, the parameters of which, however, differ only slightly, and only one molecule is depicted in Figure 1. As expected, the C-P distances to the ylidic carbon atom are different. The $\mathrm{C}-\mathrm{PPh}_{3}$ bond length amounts to $168.8(3) \mathrm{pm}$ while the $\mathrm{C}-\mathrm{P}(\mathrm{O}) \mathrm{Ph}_{2}$ bond is longer with 171.7(3) pm. The short P-C bond is located between that of $\mathrm{C}\left(\mathrm{PPh}_{3}\right)_{2}$ (163.5) [12] and that of the cation $\left(\mathrm{HC}\left\{\mathrm{PPh}_{3}\right\}_{2}\right)^{+}$(mean value of $169.9 \mathrm{pm}$ from about 10 compounds) [7], indicating a decreasing P-C double bond character down the row $\mathrm{C}\left(\mathrm{PPh}_{3}\right)_{2}>\mathbf{2}\left(\mathrm{C}-\mathrm{PPh}_{3}\right)>\left(\mathrm{HC}\left\{\mathrm{PPh}_{3}\right\}_{2}\right)^{+}>\mathbf{2}\left(\mathrm{C}-\mathrm{P}(\mathrm{O}) \mathrm{Ph}_{2}\right)$ arising from variable backbonding of the occupied $\mathrm{p}$ orbital at the ylidic $\mathrm{C}$ atom into $\mathrm{P}-\mathrm{C}_{\mathrm{Ph}} \sigma^{*}$ orbitals [13]. The $\mathrm{P}-\mathrm{O}$ distance amounts to $148.9(2) \mathrm{pm}$ and is close to that in $\mathrm{OPPh}_{3}(148.3(2) \mathrm{pm})$ [14]. With $127.5(2)^{\circ}$ the P-C-P angle is not far away from that of an $\mathrm{sp}^{2}$ carbon atom and more acute than the related angle in the cation $\left(\mathrm{HC}\left\{\mathrm{PPh}_{3}\right\}_{2}\right)^{+}$, probably an effect of the missing phenyl group in $\mathbf{2}$, which is responsible for steric repulsion in the cation and related adducts of $\mathrm{C}\left(\mathrm{PPh}_{3}\right)_{2}$. 
Table 1. Crystal data and structure refinement details for the compounds $2,5,6$, and $7 \cdot \mathrm{C}_{7} \mathrm{H}_{8}, \mathbf{8}$, and 9.

\begin{tabular}{|c|c|c|c|c|c|c|}
\hline & 2 & 5 & 6 & 7. $\mathrm{C}_{7} \mathrm{H}_{8}$ & 8 & 9 \\
\hline Formula & $\mathrm{C}_{31} \mathrm{H}_{26} \mathrm{OP}_{2}$ & $\mathrm{C}_{31} \mathrm{H}_{26} \mathrm{BF}_{3} \mathrm{OP}_{2}$ & $\mathrm{C}_{31} \mathrm{H}_{28} \mathrm{~B}_{3} \mathrm{~F}_{9} \mathrm{O}_{2} \mathrm{P}_{2}$ & $\mathrm{C}_{38} \mathrm{H}_{35} \mathrm{~B}_{2} \mathrm{I}_{7} \mathrm{OP}_{2}$ & $\mathrm{C}_{31} \mathrm{H}_{26} \mathrm{Cl}_{2} \mathrm{OP}_{2} \mathrm{Sn}$ & $\mathrm{C}_{62} \mathrm{H}_{45} \mathrm{Hg}_{2} \mathrm{I}_{6} \mathrm{O}_{2} \mathrm{P}_{4}$ \\
\hline $\mathrm{Mw} / \mathrm{g} \cdot \mathrm{mol}^{-1}$ & 476.49 & 544.30 & 697.92 & 1479.56 & 666.05 & 2117.51 \\
\hline $\mathrm{a} / \mathrm{pm}$ & $1004.8(1)$ & $1151.7(2)$ & $988.6(2)$ & $1108.0(1)$ & $1496.9(2)$ & $1194.0(1)$ \\
\hline $\mathrm{b} / \mathrm{pm}$ & $1476.5(2)$ & $1392.1(2)$ & $1059.4(2)$ & $1476.5(2)$ & $2061.0(3)$ & $1094.2(1)$ \\
\hline $\mathrm{c} / \mathrm{pm}$ & $1832.9(3)$ & $1653.8(3)$ & $1722.5(2)$ & $1444.4(2)$ & $1825.0(2)$ & $2552.1(2)$ \\
\hline$\alpha /^{\circ}$ & $107.93(1)$ & 90 & $79.46(2)$ & 90 & 90 & 90 \\
\hline$\beta /^{\circ}$ & $98.55(1)$ & $97.63(1)$ & $78.46(2)$ & $106.50(1)$ & 90 & $100.36(1)$ \\
\hline$\gamma /{ }^{\circ}$ & $101.09(1)$ & 90 & $65.68(2)$ & 90 & 90 & 90 \\
\hline Crystal size/mm & $0.32 \times 0.14 \times 0.08$ & $0.17 \times 0.17 \times 0.04$ & $0.14 \times 0.06 \times 0.05$ & $0.24 \times 0.09 \times 0.05$ & $0.13 \times 0.12 \times 0.04$ & $0.18 \times 0.11 \times 0.09$ \\
\hline Volume $/ \mathrm{pm}^{3} \cdot 10^{6}$ & $2475.2(6)$ & $2628.0(8)$ & $1600.5(5)$ & $2265.7(5)$ & $5630(1)$ & $3279.9(5)$ \\
\hline $\mathrm{Z}$ & 4 & 4 & 2 & 2 & 8 & 2 \\
\hline $\mathrm{d}_{\mathrm{calc}} / \mathrm{g} \cdot \mathrm{cm}^{-3}$ & 1.279 & 1.376 & 1.448 & 2.169 & 1.571 & 2.144 \\
\hline Crystal system & triclinic & monoclinic & triclinic & monoclinic & orthorhombic & monoclinic \\
\hline Space group & $\mathrm{P} \overline{1}$ (No. 2) & $\mathrm{P} 2_{1} / \mathrm{n}($ No. 14$)$ & Pì (No. 2) & $\mathrm{P} 2{ }_{1}$ (No. 4) & Pbca (No. 61) & $\mathrm{P} 2{ }_{1} / \mathrm{n}$ (No. 14) \\
\hline Diffractometer & IPDS I (Stoe) & IPDS II (Stoe) & IPDS I (Stoe) & IPDS II (Stoe) & IPDS II (Stoe) & IPDS I (Stoe) \\
\hline Radiation & Mo-K ${ }_{\alpha}$ & Mo-K ${ }_{\alpha}$ & Mo-K ${ }_{\alpha}$ & Mo-K ${ }_{\alpha}$ & Mo-K ${ }_{\alpha}$ & Mo-K ${ }_{\alpha}$ \\
\hline
\end{tabular}




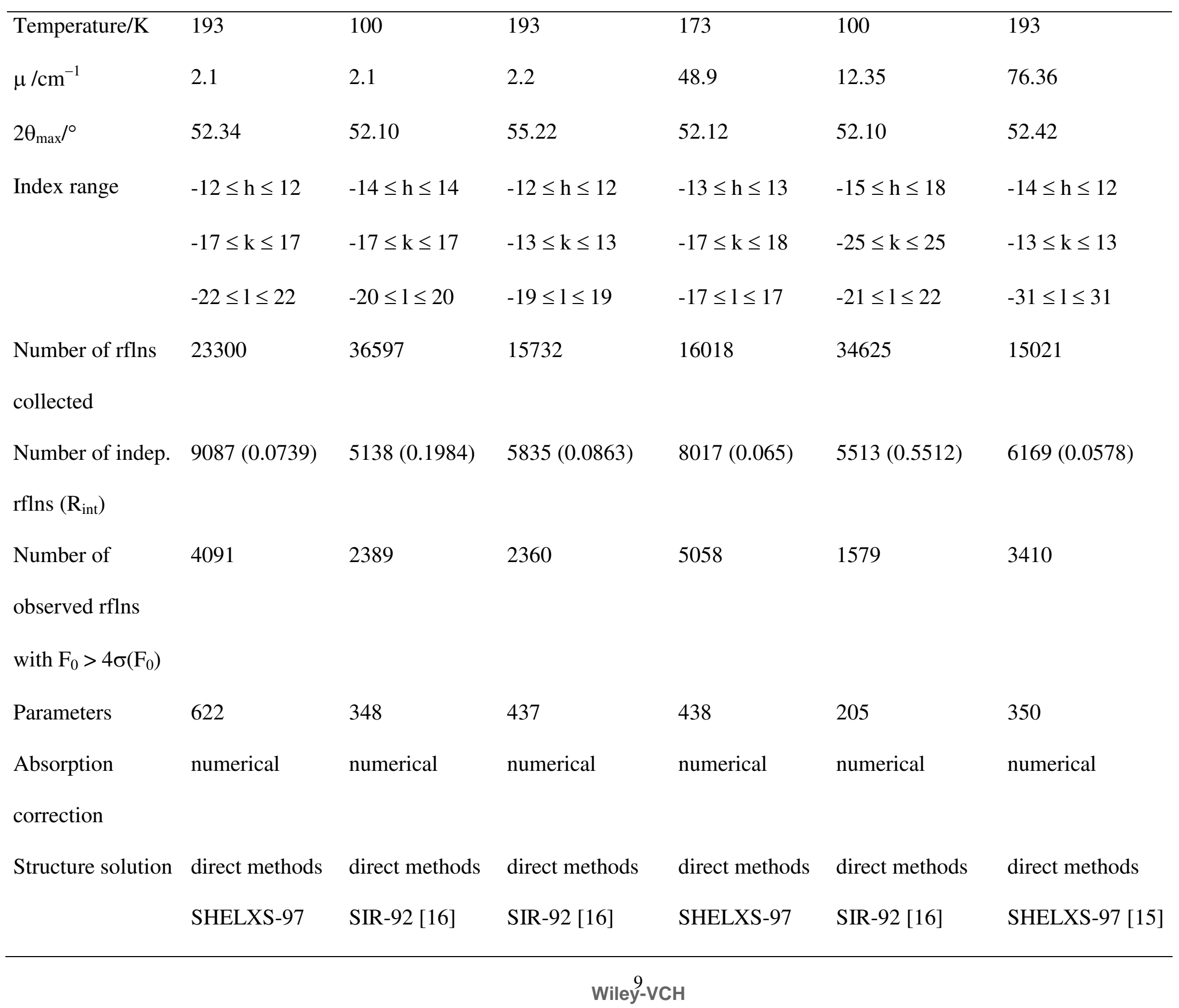


[15]

\begin{tabular}{|c|c|c|c|c|c|c|}
\hline Refinement & SHELXL-97 & SHELXL-97 & SHELXL-97 [17] & SHELXL-97 & SHELXS-97 [15] & SHELXL-97 [17] \\
\hline against $\mathrm{F}^{2}$ & [17] & [17] & & [17] & & \\
\hline Flack-Parameter & - & - & - & $-0.05(3)$ & - & - \\
\hline $\mathrm{H}$ atoms & calculated & calculated & calculated & calculated & calculated & calculated \\
\hline & positions with & positions with & positions with & positions with & positions with & positions with \\
\hline & common & common & common & common & common & common \\
\hline & displacement & displacement & displacement & displacement & displacement & displacement \\
\hline & parameter, $\mathrm{H}(1)$ & parameter & parameter, $\mathrm{H}(1)$, & parameter & parameter & parameter, $\mathrm{H}(1)$, \\
\hline & was refined free & & $\mathrm{H}(2), \mathrm{H}(3)$ were & & & $\mathrm{H}(2)$ were \\
\hline & & & refined free & & & refined free \\
\hline $\mathrm{R}_{1}$ & 0.0361 & 0.0608 & 0.0364 & 0.0411 & 0.0872 & 0.0367 \\
\hline $\mathrm{wR}_{2}$ (all data) & 0.0651 & 0.1299 & 0.0595 & 0.0611 & 0.2199 & 0.0834 \\
\hline max. electron & 0.25 & 0.68 & 0.13 & 0.72 & 1.007 & 1.413 \\
\hline density & & & & & & \\
\hline${ }^{\circ} \mathrm{left} / \mathrm{e} / \mathrm{pm}^{3} \cdot 10^{-}$ & & & & & & \\
\hline
\end{tabular}

[15] 


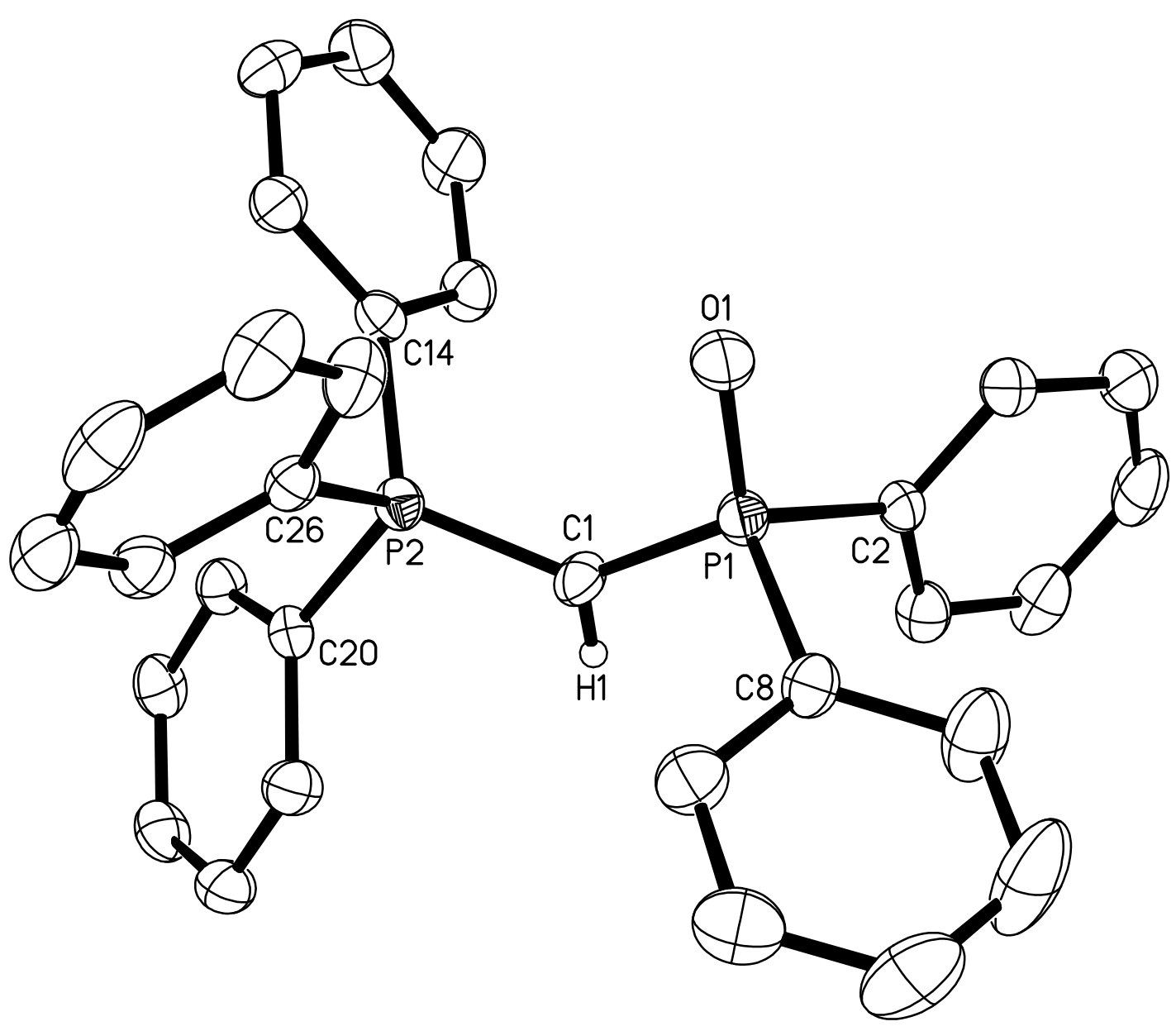

Figure 1. Molecular structure of $\mathrm{Ph}_{3} \mathrm{PCHP}(\mathrm{O}) \mathrm{Ph}_{2}$ (2) with thermal ellipsoids at $40 \%$ probability, the hydrogen atoms are omitted for clarity.

Table 2 Selected bond lengths/pm and angles $/{ }^{\circ}$ in one of the two independent molecules of 2

$\begin{array}{llll}\mathrm{P}(1)-\mathrm{O}(1) & 148.9(2) & \mathrm{P}(1)-\mathrm{C}(1) & 171.7(3) \\ \mathrm{P}(1)-\mathrm{C}(2) & 181.2(3) & \mathrm{P}(1)-\mathrm{C}(8) & 182.2(3) \\ \mathrm{P}(2)-\mathrm{C}(1) & 168.8(3) & \mathrm{P}(2)-\mathrm{C}(14) & 182.0(3)\end{array}$




\begin{tabular}{llll}
\hline $\mathrm{P}(2)-\mathrm{C}(20)$ & $180.7(2)$ & $\mathrm{P}(2)-\mathrm{C}(26)$ & $181.9(3)$ \\
$\mathrm{C}(1)-\mathrm{H}(1)$ & $0.85(3)$ & & \\
& & & \\
$\mathrm{O}(1)-\mathrm{P}(1)-\mathrm{C}(1)$ & $114.1(1)$ & $\mathrm{O}(1)-\mathrm{P}(1)-\mathrm{C}(2)$ & $111.2(1)$ \\
$\mathrm{O}(1)-\mathrm{P}(1)-\mathrm{C}(8)$ & $112.1(1)$ & $\mathrm{C}(1)-\mathrm{P}(1)-\mathrm{C}(2)$ & $109.4(2)$ \\
$\mathrm{C}(1)-\mathrm{P}(1)-\mathrm{C}(8)$ & $107.8(1)$ & $\mathrm{C}(2)-\mathrm{P}(1)-\mathrm{C}(8)$ & $101.4(1)$ \\
$\mathrm{C}(1)-\mathrm{P}(2)-\mathrm{C}(14)$ & $116.3(1)$ & $\mathrm{C}(1)-\mathrm{P}(2)-\mathrm{C}(20)$ & $105.3(2)$ \\
$\mathrm{C}(1)-\mathrm{P}(2)-\mathrm{C}(26)$ & $116.9(2)$ & $\mathrm{C}(14)-\mathrm{P}(2)-\mathrm{C}(20)$ & $106.9(1)$ \\
$\mathrm{C}(14)-\mathrm{P}(2)-\mathrm{C}(26)$ & $103.6(1)$ & $\mathrm{C}(20)-\mathrm{P}(2)-\mathrm{C}(26)$ & $107.2(1)$ \\
$\mathrm{P}(1)-\mathrm{C}(1)-\mathrm{P}(2)$ & $127.5(2)$ & $\mathrm{P}(1)-\mathrm{C}(1)-\mathrm{H}(1)$ & $116(2)$ \\
$\mathrm{P}(2)-\mathrm{C}(1)-\mathrm{H}(1)$ & $116(2)$ & &
\end{tabular}

\subsection{Crystal structure of $\left[\mathrm{Ph}_{3} \mathrm{PCHP}\left(\mathrm{OBF}_{3}\right) \mathrm{Ph}_{2}\right](\mathbf{5})$}

The molecular structure of $\mathbf{5}$ is shown in Figure 2. The coordination of a $\mathrm{BF}_{3}$ molecule at the oxygen atom of 2 leads to an elongation of the P-O bond length by about 8 pm to 157.3(3) pm indicating a dramatic loss of $\pi$ character; this is less operative in $\left[\left(\mathrm{Ph}_{3} \mathrm{PO}\right) \mathrm{BF}_{3}\right]$, where the elongation amounts to 4 pm only [18]. A similar elongation is found in the compounds [ $\left.\left(\mathrm{Ph}_{3} \mathrm{PO}\right) \mathrm{AlX}_{3}\right](\mathrm{X}=\mathrm{Cl}, \mathrm{Br})$ [19]. As counterweight, the $\mathrm{B}-\mathrm{O}$ bond length in 5 of $148.8(6) \mathrm{pm}$ is appreciably shorter than that in $\left[\left(\mathrm{Ph}_{3} \mathrm{PO}\right) \mathrm{BF}_{3}\right](151.6(6) \mathrm{pm})$. The $\mathrm{P}-\mathrm{O}-\mathrm{B}$ angles in both compounds are close together with 133.4(3) in $\mathbf{5}$ and 134.5(2) in the phosphane oxide adduct. In going from 2 to 5 the P-C-P angle opens to $131.7(3)^{\circ}$. The influence of the Lewis acid induces also changes in the $\mathrm{P}-\mathrm{C}$ bonding situation. With the $\mathrm{C}-\mathrm{P}(\mathrm{O}) \mathrm{Ph}_{2}$ bond length of $168.1(4)$ and the $\mathrm{C}-\mathrm{PPh}_{3}$ bond length of $171.6(4)$ a reverse situation to 2 occurs with a shifting of the partial double bond to the other side, more directed to the PO group. The same effects on the P-O bond are observed in 2 were a $\mathrm{W}(\mathrm{CO})_{5}$ group is 
bonded to the oxygen atom instead of $\mathrm{BF}_{3}$, however, the related $\mathrm{P}-\mathrm{C}$ bond lengths are those of 2 , but according to large standard deviations in the tungsten complex, these values should be discussed with caution [6].

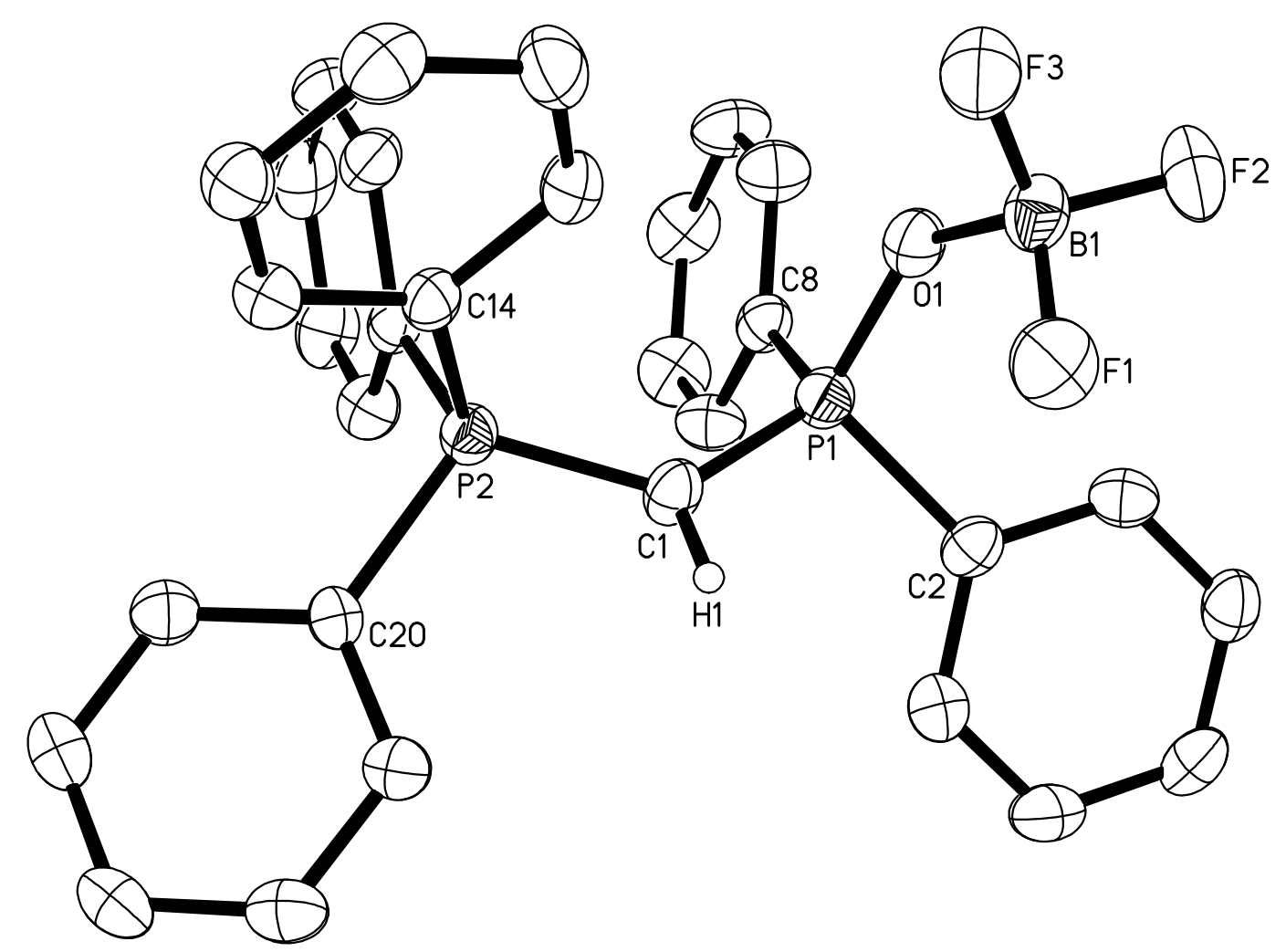

Figure 2. Molecular structure of $\left[\mathrm{Ph}_{3} \mathrm{PCHP}\left(\mathrm{OBF}_{3}\right) \mathrm{Ph}_{2}\right](5)$ with thermal ellipsoids at $40 \%$ probability, the hydrogen atoms are omitted for clarity.

Table 3. Selected bond lengths/pm and angles/ ${ }^{\circ}$ in $\mathbf{5}$.

$\begin{array}{llll}\mathrm{P}(1)-\mathrm{O}(1) & 157.3(3) & \mathrm{P}(1)-\mathrm{C}(1) & 168.1(4) \\ \mathrm{P}(1)-\mathrm{C}(2) & 179.7(4) & \mathrm{P}(1)-\mathrm{C}(8) & 179.7(4)\end{array}$




\begin{tabular}{|c|c|c|c|}
\hline$P(2)-C(1)$ & $171.6(4)$ & $\mathrm{P}(2)-\mathrm{C}(14)$ & $180.3(4)$ \\
\hline$P(2)-C(20)$ & $180.7(4)$ & $P(2)-C(26)$ & $179.6(4)$ \\
\hline $\mathrm{F}(1)-\mathrm{B}(1)$ & $137.6(6)$ & $\mathrm{F}(2)-\mathrm{B}(1)$ & $140.2(5)$ \\
\hline $\mathrm{F}(3)-\mathrm{B}(1)$ & $135.9(5)$ & $\mathrm{O}(1)-\mathrm{B}(1)$ & $148.8(6)$ \\
\hline $\mathrm{C}(1)-\mathrm{H}(1)$ & $93(4)$ & & \\
\hline $\mathrm{O}(1)-\mathrm{P}(1)-\mathrm{C}(1)$ & $118.9(2)$ & $\mathrm{O}(1)-\mathrm{P}(1)-\mathrm{C}(2)$ & $108.9(2)$ \\
\hline $\mathrm{O}(1)-\mathrm{P}(1)-\mathrm{C}(8)$ & $101.4(2)$ & $\mathrm{C}(1)-\mathrm{P}(1)-\mathrm{C}(2)$ & $107.3(2)$ \\
\hline$C(1)-P(1)-C(8)$ & $114.4(2)$ & $C(2)-P(1)-C(8)$ & $105.1(2)$ \\
\hline$C(1)-P(2)-C(14)$ & $113.5(2)$ & $C(1)-P(2)-C(20)$ & $110.7(2)$ \\
\hline$C(1)-P(2)-C(26)$ & $112.0(2)$ & $\mathrm{C}(14)-\mathrm{P}(2)-\mathrm{C}(20)$ & $104.8(2)$ \\
\hline$C(14)-P(2)-C(26)$ & $107.2(2)$ & $C(20)-P(2)-C(26)$ & $108.2(2)$ \\
\hline $\mathrm{P}(1)-\mathrm{O}(1)-\mathrm{B}(1)$ & $133.4(3)$ & $P(1)-C(1)-P(2)$ & $131.7(3)$ \\
\hline$F(1)-B(1)-F(2)$ & $109.7(4)$ & $\mathrm{F}(1)-\mathrm{B}(1)-\mathrm{F}(3)$ & $111.1(4)$ \\
\hline $\mathrm{F}(1)-\mathrm{B}(1)-\mathrm{O}(1)$ & $110.0(4)$ & $\mathrm{F}(2)-\mathrm{B}(1)-\mathrm{F}(3)$ & $110.2(4)$ \\
\hline $\mathrm{F}(2)-\mathrm{B}(1)-\mathrm{O}(1)$ & $106.9(3)$ & $\mathrm{F}(3)-\mathrm{B}(1)-\mathrm{O}(1)$ & $108.8(4)$ \\
\hline$P(1)-C(1)-H(1)$ & $114(2)$ & $\mathrm{P}(2)-\mathrm{C}(1)-\mathrm{H}(1)$ & $112(2)$ \\
\hline
\end{tabular}

3.3 Crystal structure of $\left[\mathrm{Ph}_{3} \mathrm{PCH}_{2} \mathrm{P}\left(\mathrm{OBF}_{3}\right) \mathrm{Ph}_{2}\right]\left[(\mu-\mathrm{OH}) \mathrm{B}_{2} \mathrm{~F}_{6}\right](6)$

In the solid state the compound forms a centrosymmetric dimer and the two units are linked by $\mathrm{H} \cdots \mathrm{F}$ bridges. A further $\mathrm{H} \cdots \mathrm{F}$ bridge exists between $\mathrm{H}(2)$ and $\mathrm{F}(4)$ of the anion with a $\mathrm{C}(1)-\mathrm{H}(2) \cdots \mathrm{F}(4)$ distance of 326.1(4) pm. The complex can be seen as a protonation product upon addition of the hypothetical acid $\mathrm{H}\left[\mathrm{HOB}_{2} \mathrm{~F}_{6}\right]$ at the Lewis base $\mathbf{5}$, and the crystal structure of the dimer unit is shown in Figure 3 . The unusual Wiley-V 14 CH 
and as yet unique anion $\left[\mathrm{HOB}_{2} \mathrm{~F}_{6}\right]^{-}$was described earlier with a carbenoid counter cation [20]. The bonding situation around the P-C-P group changed dramatically upon conversion of the central $\mathrm{sp}^{2}$ carbon atom into a sp $^{3}$ carbon atom on protonation to give a type $\mathbf{C}$ salt. According to a missing back donation, the P-C bond lengths increased to 181.3(3) and 179.9(3) pm and correspond to normal single bonds. The P-O bond length amounts to $152.9(2)$ and is in between that of $\mathbf{1}$ and $\mathbf{5}$. Relative to $\mathbf{5}$ the B-O bond length increased by about $5 \mathrm{pm}$ to $154.2(4) \mathrm{pm}$, while the P-O-B angle remained unchanged. The P-C-P angle moved into the direction of that of an $\mathrm{sp}^{3}$ carbon atom but with $119.9(2)^{\circ}$ remains still large, probably according to steric repulsion between the phenyl groups. The other angles in the distorted tetrahedral environment of the carbon atom range between $100^{\circ}(\mathrm{H}-\mathrm{C}-\mathrm{H})$ and $111^{\circ}(\mathrm{P}-\mathrm{C}-\mathrm{H})$.

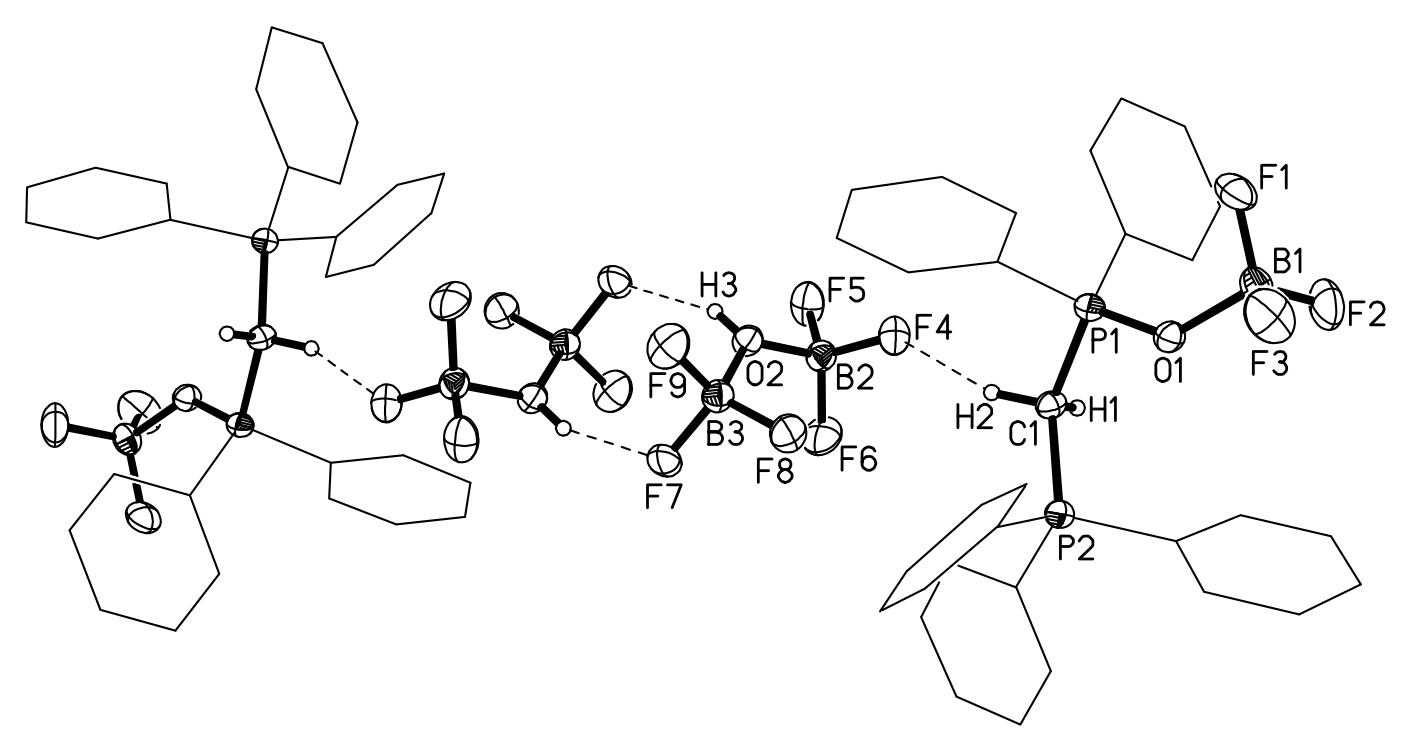

Figure 3. Molecular structure of $\left[\mathrm{Ph}_{3} \mathrm{PCH}_{2} \mathrm{P}\left(\mathrm{OBF}_{3}\right) \mathrm{Ph}_{2}\right]\left[(\mu-\mathrm{OH}) \mathrm{B}_{2} \mathrm{~F}_{6}\right](\mathbf{6})$. The two cations and two anions are connected through H-bonds to a centrosymmetrical dimer. The ellipsoids are drawn at a $40 \%$ probability level; the phenyl groups are represented as thin lines omitting the $\mathrm{H}$ atoms for clarity. 
Table 4. Selected bond lengths/pm and angles $/{ }^{\circ}$ in $\mathbf{6}$.

\begin{tabular}{|c|c|c|c|}
\hline $\mathrm{P}(1)-\mathrm{O}(1)$ & $152.9(2)$ & $\mathrm{P}(1)-\mathrm{C}(1)$ & $179.9(3)$ \\
\hline$P(1)-C(2)$ & $178.5(3)$ & $P(1)-C(8)$ & $177.3(3)$ \\
\hline$P(2)-C(1)$ & $181.3(3)$ & $P(2)-C(14)$ & $178.6(3)$ \\
\hline$P(2)-C(20)$ & $177.7(3)$ & $P(2)-C(26)$ & $178.2(3)$ \\
\hline $\mathrm{F}(1)-\mathrm{B}(1)$ & $138.8(4)$ & $\mathrm{F}(2)-\mathrm{B}(1)$ & $134.2(4)$ \\
\hline $\mathrm{F}(3)-\mathrm{B}(1)$ & $133.6(4)$ & $\mathrm{O}(1)-\mathrm{B}(1)$ & $154.2(4)$ \\
\hline $\mathrm{C}(1)-\mathrm{H}(1)$ & $87(3)$ & $\mathrm{C}(1)-\mathrm{H}(2)$ & $97(3)$ \\
\hline$F(4)-B(2)$ & $137.8(4)$ & $F(5)-B(2)$ & $137.8(4)$ \\
\hline$F(6)-B(2)$ & $135.3(4)$ & $F(7)-B(3)$ & $141.6(4)$ \\
\hline $\mathrm{F}(8)-\mathrm{B}(3)$ & $136.5(4)$ & $\mathrm{F}(9)-\mathrm{B}(3)$ & $137.1(4)$ \\
\hline $\mathrm{O}(2)-\mathrm{B}(2)$ & $151.9(4)$ & $\mathrm{O}(2)-\mathrm{B}(3)$ & $147.6(4)$ \\
\hline $\mathrm{O}(2)-\mathrm{H}(3)$ & $86(4)$ & & \\
\hline $\mathrm{O}(1)-\mathrm{P}(1)-\mathrm{C}(1)$ & $106.7(2)$ & $\mathrm{O}(1)-\mathrm{P}(1)-\mathrm{C}(2)$ & 111.2(1) \\
\hline $\mathrm{O}(1)-\mathrm{P}(1)-\mathrm{C}(8)$ & $111.6(1)$ & $C(1)-P(1)-C(2)$ & $108.5(2)$ \\
\hline$C(1)-P(1)-C(8)$ & $106.5(2)$ & $C(1)-P(2)-C(26)$ & $106.2(2)$ \\
\hline$C(1)-P(2)-C(14)$ & $109.6(2)$ & $C(1)-P(2)-C(20)$ & $113.6(2)$ \\
\hline $\mathrm{P}(1)-\mathrm{O}(1)-\mathrm{B}(1)$ & $133.4(2)$ & $\mathrm{P}(1)-\mathrm{C}(1)-\mathrm{P}(2)$ & $119.9(2)$ \\
\hline$F(1)-B(1)-F(2)$ & $110.4(3)$ & $F(1)-B(1)-F(3)$ & $110.8(4)$ \\
\hline $\mathrm{F}(1)-\mathrm{B}(1)-\mathrm{O}(1)$ & $106.9(3)$ & $\mathrm{F}(2)-\mathrm{B}(1)-\mathrm{F}(3)$ & $114.9(4)$ \\
\hline
\end{tabular}




\begin{tabular}{llll}
\hline $\mathrm{F}(2)-\mathrm{B}(1)-\mathrm{O}(1)$ & $107.4(4)$ & $\mathrm{F}(3)-\mathrm{B}(1)-\mathrm{O}(1)$ & $105.7(3)$ \\
$\mathrm{P}(1)-\mathrm{C}(1)-\mathrm{H}(1)$ & $110(2)$ & $\mathrm{P}(1)-\mathrm{C}(1)-\mathrm{H}(2)$ & $107(2)$ \\
$\mathrm{P}(2)-\mathrm{C}(1)-\mathrm{H}(1)$ & $107(2)$ & $\mathrm{P}(2)-\mathrm{C}(1)-\mathrm{H}(2)$ & $111(2)$ \\
$\mathrm{H}(1)-\mathrm{C}(1)-\mathrm{H}(2)$ & $100(3)$ & $\mathrm{B}(2)-\mathrm{O}(1)-\mathrm{B}(3)$ & $127.6(3)$ \\
$\mathrm{F}(4)-\mathrm{B}(2)-\mathrm{F}(5)$ & $111.7(3)$ & $\mathrm{F}(4)-\mathrm{B}(2)-\mathrm{F}(6)$ & $110.8(3)$ \\
$\mathrm{F}(4)-\mathrm{B}(2)-\mathrm{O}(2)$ & $107.3(3)$ & $\mathrm{F}(5)-\mathrm{B}(2)-\mathrm{F}(6)$ & $111.4(4)$ \\
$\mathrm{F}(5)-\mathrm{B}(2)-\mathrm{O}(2)$ & $105.3(3)$ & $\mathrm{F}(6)-\mathrm{B}(2)-\mathrm{O}(2)$ & $110.1(3)$ \\
$\mathrm{F}(7)-\mathrm{B}(3)-\mathrm{F}(8)$ & $109.9(3)$ & $\mathrm{F}(7)-\mathrm{B}(3)-\mathrm{F}(9)$ & $108.0(3)$ \\
$\mathrm{F}(7)-\mathrm{B}(3)-\mathrm{O}(2)$ & $108.8(3)$ & $\mathrm{F}(8)-\mathrm{B}(3)-\mathrm{F}(9)$ & $112.2(4)$ \\
$\mathrm{F}(8)-\mathrm{B}(3)-\mathrm{O}(2)$ & $109.5(3)$ & $\mathrm{F}(9)-\mathrm{B}(3)-\mathrm{O}(2)$ & $108.2(3)$ \\
$\mathrm{B}(2)-\mathrm{O}(2)-\mathrm{H}(3)$ & $102(2)$ & $\mathrm{B}(3)-\mathrm{O}(2)-\mathrm{H}(3)$ & $124(2)$
\end{tabular}

\subsection{Crystal structure of $\left[\mathrm{Ph}_{3} \mathrm{PCH}_{2} \mathrm{P}\left(\mathrm{OBI}_{3}\right) \mathrm{Ph}_{2}\right]\left[\mathrm{BI}_{4}\right]\left(7 \cdot \mathrm{C}_{7} \mathrm{H}_{8}\right)$}

The compound crystallizes with one disordered toluene molecule without contacts to the salt-like compound and the molecular structure of 7 is shown in Figure 4. The replacement of the $\mathrm{BF}_{3}$ group by the $\mathrm{BI}_{3}$ group has no dramatic effect on the parameters of the cation; only the B-O bond is about 5 pm shorter and close to that of $\mathbf{5}$ which is due to the stronger Lewis acidity of $\mathrm{BI}_{3}$ relative to $\mathrm{BF}_{3}$. The $\mathrm{P}-\mathrm{C}$ bond lengths show the same trend as reported for the cation of 6 . Weak $\mathrm{H}$ bridges between $\mathrm{H}(2)$ of the cation and $\mathrm{I}(4)$ of the anion exist $(\mathrm{C}(1)-\mathrm{H}(2) \cdots \cdot \mathrm{I}(4)=399(1) \mathrm{pm})$, which lead to a long $\mathrm{B}(2)-\mathrm{I}(4)$ distance of 228(1) pm relative to the three others with a mean B-I distance of 223 pm; all B-I distances are about 10 pm longer than those in the planar $\mathrm{BI}_{3}$ molecule [21]. 


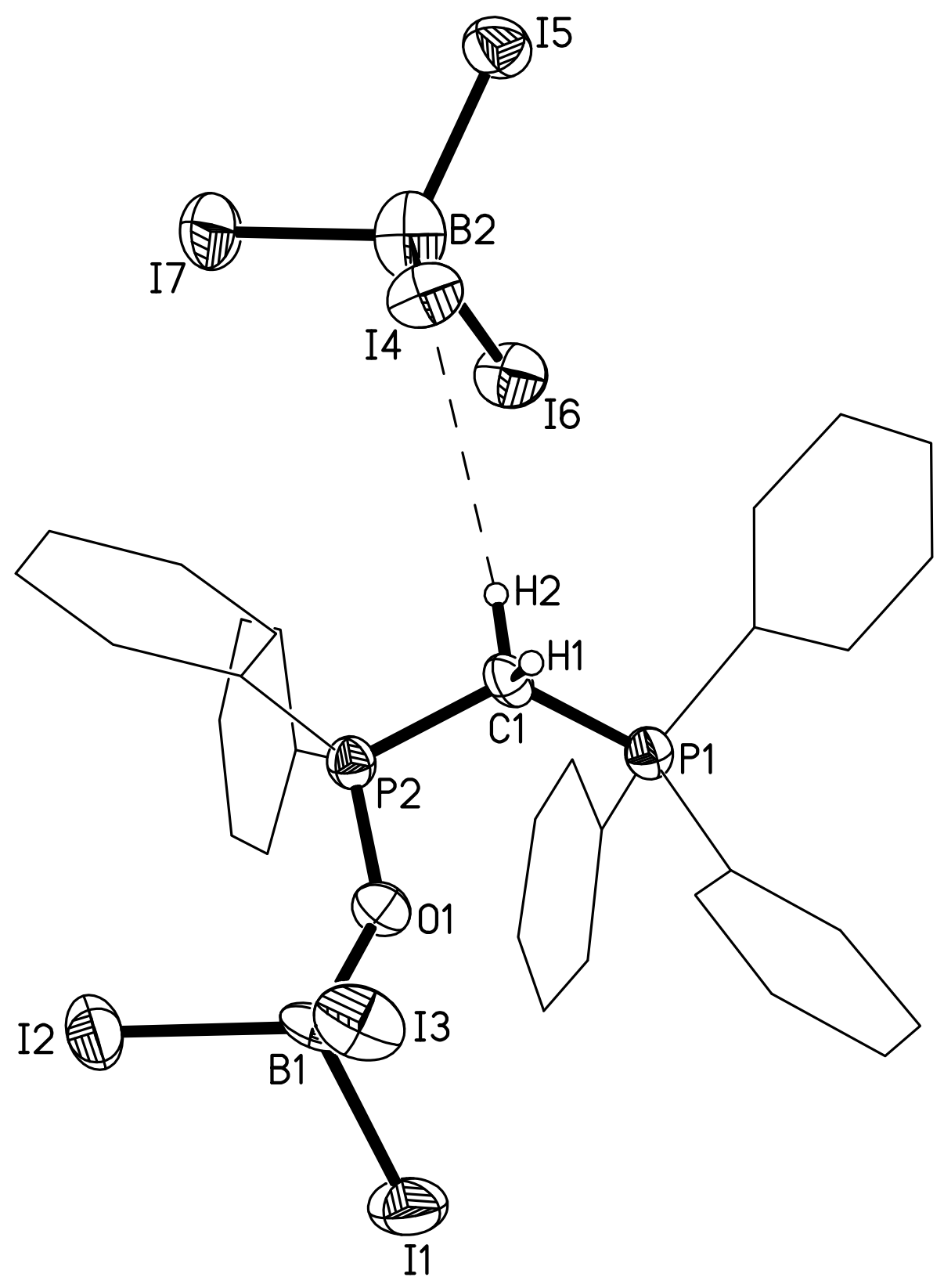

Figure 4. Molecular structure of $\left[\mathrm{Ph}_{3} \mathrm{PCH}_{2} \mathrm{P}\left(\mathrm{OBI}_{3}\right) \mathrm{Ph}_{2}\right]\left[\mathrm{BI}_{4}\right](7)$. The ellipsoids are drawn at a $40 \%$ probability level; the phenyl groups are represented as thin lines omitting the $\mathrm{H}$ atoms for clarity.

Wiley- $18 \mathrm{CH}$ 
Table 5. Selected bond lengths/pm and angles $/{ }^{\circ}$ in $\mathbf{7} \cdot \mathrm{C}_{7} \mathrm{H}_{8}$.

\begin{tabular}{|c|c|c|c|}
\hline $\mathrm{I}(1)-\mathrm{B}(1)$ & $221(1)$ & $\mathrm{I}(2)-\mathrm{B}(1)$ & $222(1)$ \\
\hline $\mathrm{I}(3)-\mathrm{B}(1)$ & $229(1)$ & $\mathrm{P}(1)-\mathrm{C}(1)$ & $180(1)$ \\
\hline$P(1)-C(2)$ & $177.0(9)$ & $P(1)-C(8)$ & 179(1) \\
\hline$P(1)-C(14)$ & $176(1)$ & $\mathrm{P}(2)-\mathrm{O}(1)$ & $154.5(1)$ \\
\hline $\mathrm{P}(2)-\mathrm{C}(1)$ & $180.4(8)$ & $P(2)-C(20)$ & $175(1)$ \\
\hline$P(2)-C(26)$ & $178(1)$ & $\mathrm{O}(1)-\mathrm{B}(1)$ & $148(1)$ \\
\hline $\mathrm{C}(1)-\mathrm{H}(1)$ & 99 & $\mathrm{C}(1)-\mathrm{H}(2)$ & 99 \\
\hline $\mathrm{I}(4)-\mathrm{B}(2)$ & $228(1)$ & $\mathrm{I}(5)-\mathrm{B}(2)$ & $222(2)$ \\
\hline $\mathrm{I}(6)-\mathrm{B}(2)$ & $224(2)$ & $\mathrm{I}(7)-\mathrm{B}(2)$ & $222(1)$ \\
\hline$C(1)-P(1)-C(2)$ & $107.1(5)$ & $C(1)-P(1)-C(8)$ & $110.9(5)$ \\
\hline $\mathrm{C}(1)-\mathrm{P}(1)-\mathrm{C}(14)$ & $110.3(5)$ & $\mathrm{O}(1)-\mathrm{P}(2)-\mathrm{C}(1)$ & $104.7(4)$ \\
\hline $\mathrm{O}(1)-\mathrm{P}(2)-\mathrm{C}(20)$ & $116.3(4)$ & $\mathrm{O}(1)-\mathrm{P}(2)-\mathrm{C}(26)$ & $111.0(5)$ \\
\hline $\mathrm{C}(1)-\mathrm{P}(2)-\mathrm{C}(20)$ & $106.8(5)$ & $C(1)-P(2)-C(26)$ & $108.0(4)$ \\
\hline $\mathrm{P}(2)-\mathrm{O}(1)-\mathrm{B}(1)$ & $139.0(7)$ & $\mathrm{P}(1)-\mathrm{C}(1)-\mathrm{P}(2)$ & $120.9(6)$ \\
\hline $\mathrm{I}(1)-\mathrm{B}(1)-\mathrm{I}(2)$ & $109.6(4)$ & $\mathrm{I}(1)-\mathrm{B}(1)-\mathrm{I}(3)$ & $109.9(5)$ \\
\hline $\mathrm{I}(1)-\mathrm{B}(1)-\mathrm{O}(1)$ & $107.3(7)$ & $\mathrm{I}(2)-\mathrm{B}(1)-\mathrm{O}(1)$ & $112.9(7)$ \\
\hline $\mathrm{I}(3)-\mathrm{B}(1)-\mathrm{O}(1)$ & $108.1(6)$ & $\mathrm{P}(1)-\mathrm{C}(1)-\mathrm{H}(1)$ & 107 \\
\hline $\mathrm{P}(1)-\mathrm{C}(1)-\mathrm{H}(2)$ & 107 & $\mathrm{P}(2)-\mathrm{C}(1)-\mathrm{H}(1)$ & 107 \\
\hline
\end{tabular}



$\mathrm{P}(2)-\mathrm{C}(1)-\mathrm{H}(2)$
107
$\mathrm{H}(1)-\mathrm{C}(1)-\mathrm{H}(2)$
106

\subsection{Crystal structure of $\left[\mathrm{Ph}_{3} \mathrm{PCHP}\left(\mathrm{OSnCl}_{2}\right) \mathrm{Ph}_{2}\right](\mathbf{8})$}

Similar to the $\mathrm{BF}_{3}$ adduct $\mathbf{5}$, the tin derivative $\mathbf{8}$ can be considered as type $\mathbf{A}$ compound; the molecular structure is depicted in Figure 5. Thus, the relevant bond lengths $\mathrm{P}(1)-\mathrm{O}, \mathrm{P}(1)-\mathrm{C}(1)$, and $\mathrm{P}(2)-\mathrm{C}(1)$, which are influenced by the coordination of the tin atom, show the same trend in shifting of the partial double bond more directed to the PO bond relative to the starting compound 2 . The Sn-O bond length amounts to 212(1) pm, which is shorter than that in the comparable complex $\left[\mathrm{Cl}_{2} \mathrm{Sn}\left(\mathrm{OC}(\mathrm{O}) \mathrm{C}\left\{\mathrm{PPh}_{3}\right\}_{2}\right)\right](214.3(4) \mathrm{pm})$ described by us recently [22]. Similar $\mathrm{Sn}-\mathrm{O}$ bond lenghts in $\mathrm{SnCl}_{2}$ addition compounds vary between $252 \mathrm{pm}$ in the dioxane adduct [23] and $230 \mathrm{pm}$ in the dihydrate [24]; the structures of other compounds with the simple $\mathrm{Cl}_{2} \mathrm{SnO}$ core have not been reported so far. The two $\mathrm{Sn}-\mathrm{Cl}$ bond lengths in $\mathbf{8}$ are not equal and differ by about $3 \mathrm{pm}$. For the tin atom a typical tetrahedral environment is achieved where one coordination site is occupied by a free pair of electrons. Together with the $(\mathrm{CO})_{5} \mathrm{~W}$ adduct $\mathbf{3}$, the compounds $\mathbf{5}$ and $\mathbf{8}$ represent the only type A compounds existing as yet. 
Figure 5. Molecular structure of $\left[\mathrm{Ph}_{3} \mathrm{PCHP}\left(\mathrm{OSnCl}_{2}\right) \mathrm{Ph}_{2}\right](\mathbf{8})$. The ellipsoids are drawn at a $40 \%$ probability level; the phenyl rings are refined as rigid groups and are represented as thin lines omitting the $\mathrm{H}$ atoms for clarity.

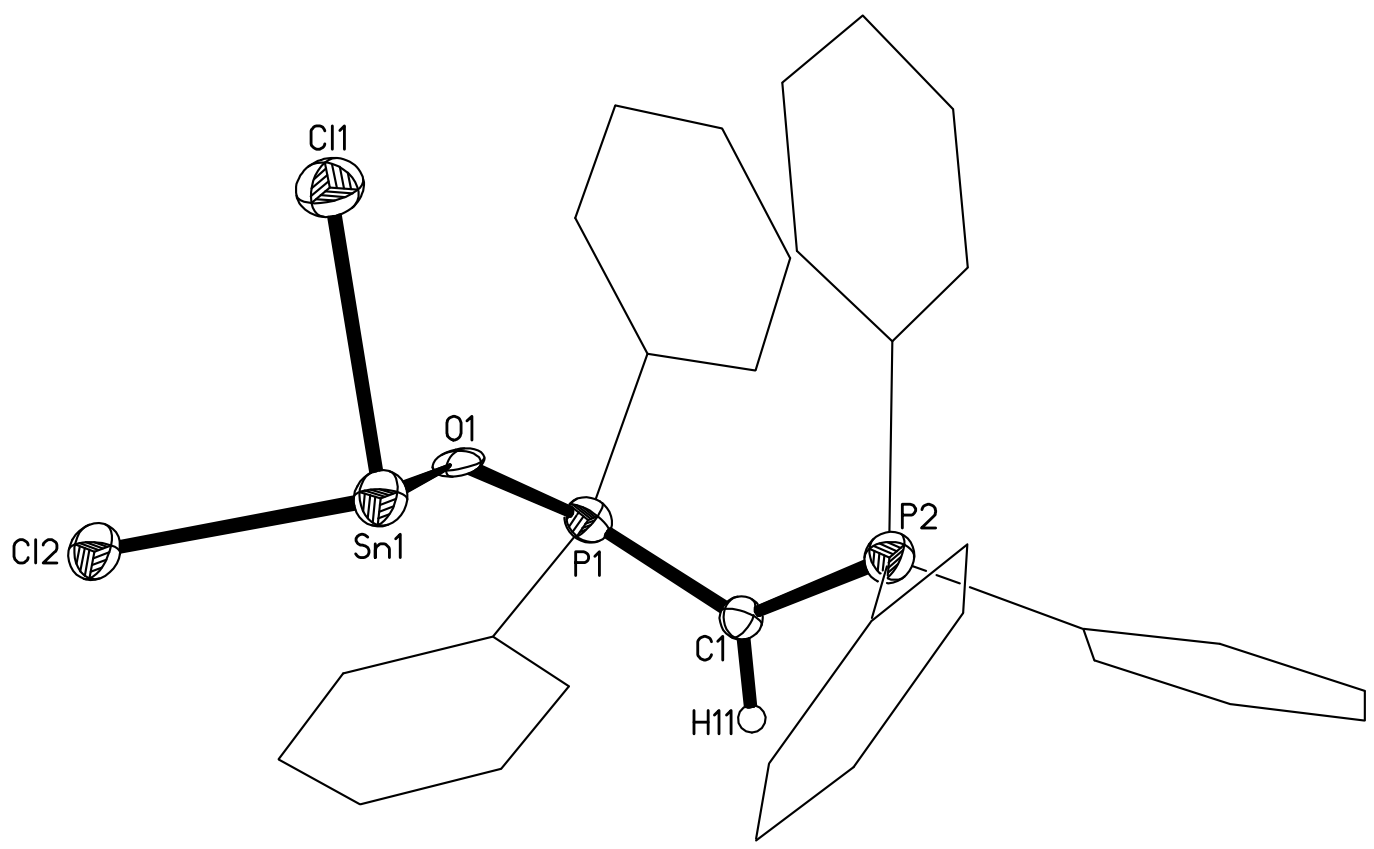

Table 6. Selected bond lengths/pm and angles $/{ }^{\circ}$ in $\mathbf{8}$.

$\begin{array}{cccc}\mathrm{P}(1)-\mathrm{O}(1) & 156(1) & \mathrm{P}(1)-\mathrm{C}(1) & 168(2) \\ \mathrm{P}(1)-\mathrm{C}(2) & 182.0(3) & \mathrm{P}(1)-\mathrm{C}(8) & 183 \\ \mathrm{P}(2)-\mathrm{C}(1) & 172(2) & \mathrm{P}(2)-\mathrm{C}(14) & 181 \\ \mathrm{P}(2)-\mathrm{C}(20) & 183 & \mathrm{P}(2)-\mathrm{C}(26) & 180 \\ \mathrm{O}(1)-\mathrm{Sn}(1) & 212(1) & \mathrm{Cl}(1)-\mathrm{Sn}(1) & 250.0(5) \\ \mathrm{Cl}(2)-\mathrm{Sn}(1) & 247.0(5) & \mathrm{C}(1)-\mathrm{H}(11) & 95\end{array}$




\begin{tabular}{llll}
\hline $\mathrm{O}(1)-\mathrm{Sn}(1)-\mathrm{Cl}(2)$ & $90.9(3)$ & $\mathrm{O}(1)-\mathrm{Sn}(1)-\mathrm{Cl}(1)$ & $88.3(3)$ \\
$\mathrm{Cl}(2)-\mathrm{Sn}(1)-\mathrm{Cl}(1)$ & $92.5(2)$ & $\mathrm{P}(1)-\mathrm{C}(1)-\mathrm{P}(2)$ & $128(1)$ \\
$\mathrm{P}(1)-\mathrm{C}(1)-\mathrm{H}(11)$ & 115.9 & $\mathrm{P}(2)-\mathrm{C}(1)-\mathrm{H}(11)$ & 115.9 \\
$\mathrm{P}(1)-\mathrm{O}(1)-\mathrm{Sn}(1)$ & $138.1(6)$ & $\mathrm{O}(1)-\mathrm{P}(1)-\mathrm{C}(1)$ & $119.2(7)$ \\
$\mathrm{O}(1)-\mathrm{P}(1)-\mathrm{C}(2)$ & $105.6(4)$ & $\mathrm{C}(1)-\mathrm{P}(1)-\mathrm{C}(2)$ & $108.1(5)$ \\
$\mathrm{O}(1)-\mathrm{P}(1)-\mathrm{C}(8)$ & $105.4(4)$ & $\mathrm{C}(1)-\mathrm{P}(1)-\mathrm{C}(8)$ & $111.1(5)$ \\
$\mathrm{C}(2)-\mathrm{P}(1)-\mathrm{C}(8)$ & 106.7 & $\mathrm{C}(1)-\mathrm{P}(2)-\mathrm{C}(14)$ & $115.5(5)$ \\
$\mathrm{C}(1)-\mathrm{P}(2)-\mathrm{C}(26)$ & $108.8(5)$ & $\mathrm{C}(26)-\mathrm{P}(2)-\mathrm{C}(14)$ & 105.5 \\
$\mathrm{C}(1)-\mathrm{P}(2)-\mathrm{C}(20)$ & $112.0(6)$ & $\mathrm{C}(26)-\mathrm{P}(2)-\mathrm{C}(20)$ & 108.6 \\
$\mathrm{C}(14)-\mathrm{P}(2)-\mathrm{C}(20)$ & 106.0 & &
\end{tabular}

3.6 Crystal structure of $\left[\mathrm{Ph}_{3} \mathrm{PCH}_{2} \mathrm{P}(\mathrm{O}) \mathrm{Ph}_{2}\right]_{2}\left[\mathrm{Hg}_{2} \mathrm{I}_{6}\right](9)$

The protonation of $\mathbf{2}$ produces the cation of $\mathbf{9}$, its conjugated acid and a change in rehybridization of the carbon atom from planar $\mathrm{sp}^{2}$ to tetrahedral $\mathrm{sp}^{3}$ occurred with interruption of the $\pi$ conjugation in the P-C-PO spine. The molecular structure is shown in Figure 6. Upon protonation, both P-C bond lengths have increased by about $10 \mathrm{pm}$ with respect to 2 being now in the range of a normal P-C single bond; however, the prevailing $\mathrm{C}-\mathrm{P}(\mathrm{O})$ bond lengths in 2 and 9 are about 2 to 3 pm longer. The P-O bond length remains nearly unchanged. The addition of a further Lewis acid at the oxygen atom as in $\mathbf{6}$ or $\mathbf{7}$ leads to an increase of the P-O bond by about 5 pm. In the crystals of 9 ion triples are present, held together by $\mathrm{H} \cdots \cdot . \mathrm{I}$ bridges $(\mathrm{C}(1) \cdots \cdot \mathrm{I}(2)=388.6(8) \mathrm{pm})$ which are stacked along $\mathrm{H} \cdots \cdot \mathrm{H}-\mathrm{O}$ bridges as shown in Figure 7 . The dianion is located around an inversion center causing the fourmembered $\mathrm{Hg}-\mathrm{I}-\mathrm{Hg}-\mathrm{I}$ ring to be completely planar, and both $\mathrm{Hg}$ atoms are in a distorted tetrahedral environment. 


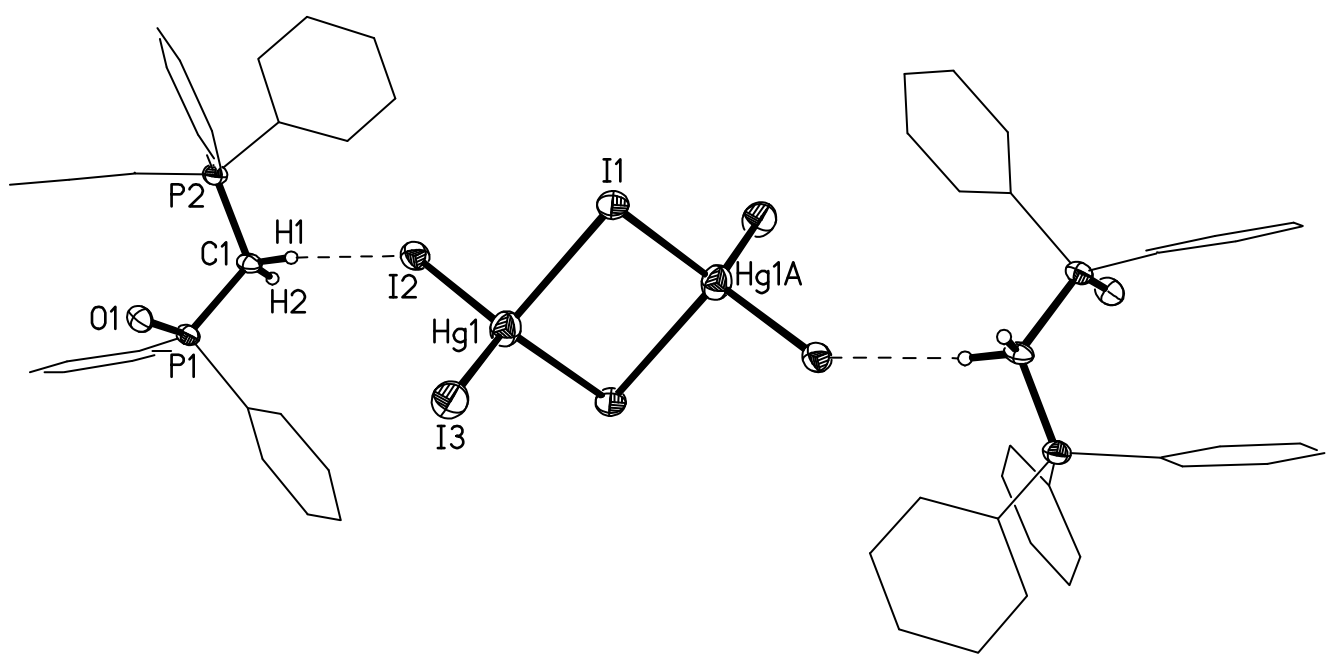

Figure 6. Molecular structure of $\left[\mathrm{Ph}_{3} \mathrm{PCH}_{2} \mathrm{P}(\mathrm{O}) \mathrm{Ph}_{2}\right]_{2}\left[\mathrm{Hg}_{2} \mathrm{I}_{6}\right](9)$. The ellipsoids are drawn at a $40 \%$ probability level; the phenyl groups are represented as thin lines omitting the $\mathrm{H}$ atoms for clarity.

Table 7. Selected bond lengths/pm and angles/ ${ }^{\circ}$ in 9.

\begin{tabular}{llll}
\hline $\mathrm{Hg}(1)-\mathrm{I}(3)$ & $267.01(8)$ & $\mathrm{Hg}(1)-\mathrm{I}(2)$ & $270.35(6)$ \\
$\mathrm{Hg}(1)-\mathrm{I}(1) \mathrm{A}$ & $280.51(7)$ & $\mathrm{Hg}(1)-\mathrm{I}(1)$ & $300.77(8)$ \\
$\mathrm{P}(1)-\mathrm{O}(1)$ & $147.9(6)$ & $\mathrm{P}(1)-\mathrm{C}(1)$ & $182.2(8)$ \\
$\mathrm{P}(1)-\mathrm{C}(2)$ & $179.2(8)$ & $\mathrm{P}(1)-\mathrm{C}(8)$ & $180.6(7)$ \\
$\mathrm{P}(2)-\mathrm{C}(1)$ & $\mathrm{P}(2)-\mathrm{C}(14)$ & $178.5(7)$ \\
$\mathrm{P}(2)-\mathrm{C}(20)$ & $179.7(8)$ & $\mathrm{P}(2)-\mathrm{C}(26)$ & $179.5(8)$ \\
$\mathrm{C}(1)-\mathrm{H}(1)$ & $179.1(9)$ & $\mathrm{C}(1)-\mathrm{H}(2)$ & $93(9)$ \\
& $101(8)$ & & \\
$\mathrm{I}(3)-\mathrm{Hg}(1)-\mathrm{I}(2)$ & $120.81(2)$ & $\mathrm{I}(3)-\mathrm{Hg}(1)-\mathrm{I}(1) \mathrm{A}$ & $118.50(3)$ \\
\hline
\end{tabular}




\begin{tabular}{llll}
\hline $\mathrm{I}(2)-\mathrm{Hg}(1)-\mathrm{I}(1) \mathrm{A}$ & $108.32(2)$ & $\mathrm{I}(3)-\mathrm{Hg}(1)-\mathrm{I}(1)$ & $107.94(2)$ \\
$\mathrm{I}(2)-\mathrm{Hg}(1)-\mathrm{I}(1)$ & $102.01(2)$ & $\mathrm{I}(1) \mathrm{A}-\mathrm{Hg}(1)-\mathrm{I}(1)$ & $94.52(2)$ \\
$\mathrm{Hg}(1) \mathrm{A}-\mathrm{I}(1)-\mathrm{Hg}(1)$ & $85.48(2)$ & $\mathrm{P}(1)-\mathrm{C}(1)-\mathrm{P}(2)$ & $118.2(4)$ \\
$\mathrm{P}(2)-\mathrm{C}(1)-\mathrm{H}(1)$ & $102(6)$ & $\mathrm{P}(1)-\mathrm{C}(1)-\mathrm{H}(1)$ & $115(5)$ \\
$\mathrm{P}(2)-\mathrm{C}(1)-\mathrm{H}(2)$ & $116(6)$ & $\mathrm{P}(1)-\mathrm{C}(1)-\mathrm{H}(2)$ & $105(6)$ \\
$\mathrm{H}(1)-\mathrm{C}(1)-\mathrm{H}(2)$ & $101(7)$ & $\mathrm{O}(1)-\mathrm{P}(1)-\mathrm{C}(2)$ & $112.3(3)$ \\
$\mathrm{O}(1)-\mathrm{P}(1)-\mathrm{C}(8)$ & $113.0(3)$ & $\mathrm{C}(2)-\mathrm{P}(1)-\mathrm{C}(8)$ & $109.6(4)$ \\
$\mathrm{O}(1)-\mathrm{P}(1)-\mathrm{C}(1)$ & $112.5(4)$ & $\mathrm{C}(2)-\mathrm{P}(1)-\mathrm{C}(1)$ & $102.3(3)$ \\
$\mathrm{C}(8)-\mathrm{P}(1)-\mathrm{C}(1)$ & $106.4(4)$ & $\mathrm{C}(14)-\mathrm{P}(2)-\mathrm{C}(1)$ & $110.1(4)$ \\
$\mathrm{C}(20)-\mathrm{P}(2)-\mathrm{C}(1)$ & $108.3(4)$ & $\mathrm{C}(26)-\mathrm{P}(2)-\mathrm{C}(1)$ & $112.0(4)$
\end{tabular}




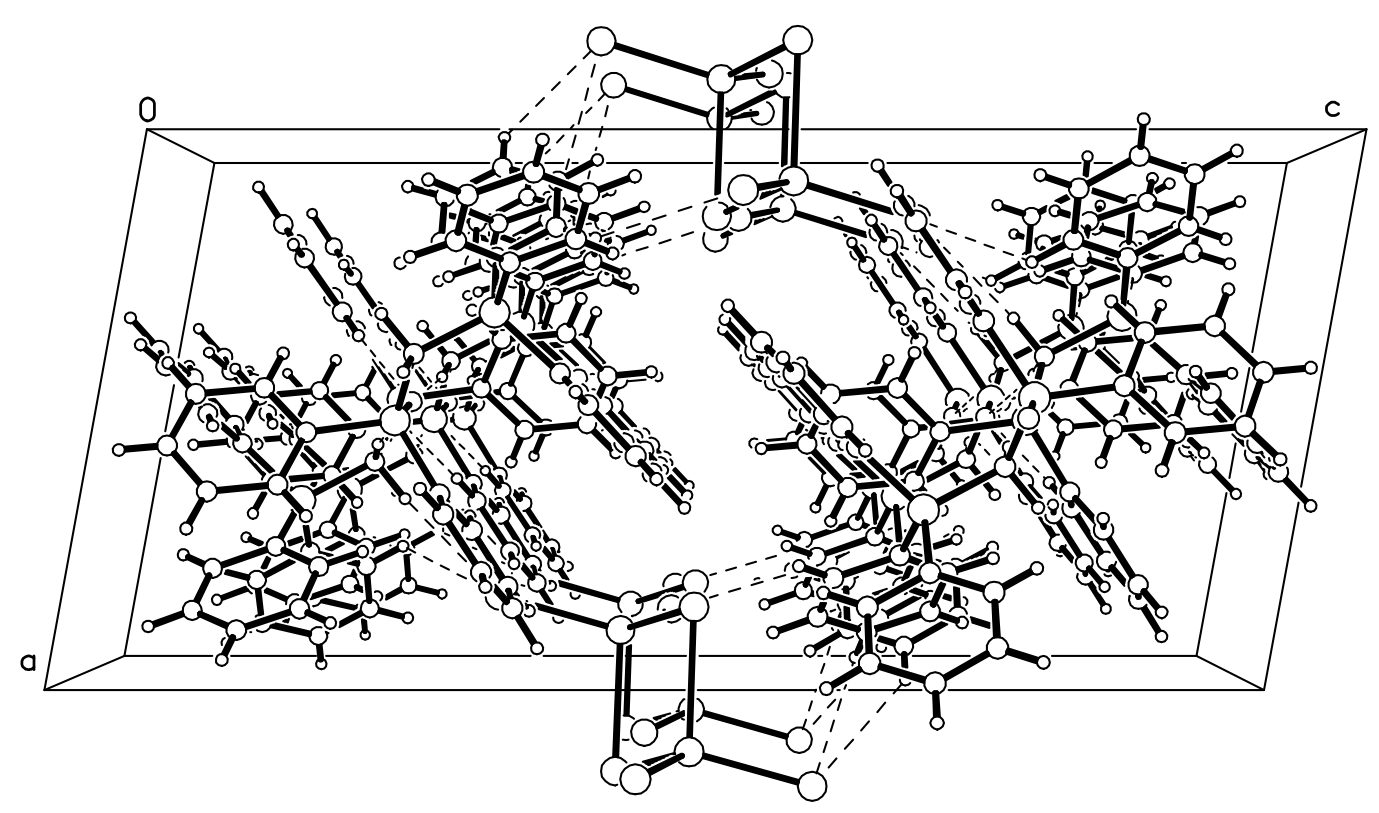

Figure 7. Crystal packing diagram of compound $\mathbf{9}$ viewed along the $b$ axis; hydrogen contacts are indicated by dashed lines.

\section{Conclusion}

The majority of the compounds presented here are side-products which were obtained with low yields during various runs for preparing addition compounds of the type LA $\leftarrow \mathbf{1}$ and not as a result of specific syntheses. Although $\mathbf{2}$ was only present in trace amounts in the starting material the adducts preferentially crystallized. It turned out that these are more soluble, less sensitive to polar solvents, and show better crystallization properties than those with 1 . In part, this was also the case during the reaction of $\mathrm{AlBr}_{3}$ with 1 in toluene, where a couple of colorless crystals of the adduct $\mathrm{Br}_{3} \mathrm{Al} \leftarrow \mathbf{1}$ have grown from a saturated toluene solution overnight and among them very few yellow crystals of 3 [7]. However, in the majority of reactions with $\mathrm{C}\left(\mathrm{PPh}_{3}\right)_{2}$ and Lewis acids in toluene or benzene no crystals of the appropriate addition compounds 
have been obtained from the saturated solutions as yet and attempts to get crystals have failed according to the properties mentioned above.

Here we could show that the neutral compound $\mathrm{Ph}_{3} \mathrm{PCHP}(\mathrm{O}) \mathrm{Ph}_{2}(2)$ has a free pair of electrons at the carbon atom and can be protonated; the results of attempted alkylation will be reported elsewhere. Other Lewis acids such as group 13 or group 14 electron deficient compounds prefer the PO oxygen atom. Thus, adducts of the type $\mathbf{A}, \mathbf{B}$, and $\mathbf{C}$ of Scheme 1 could be realized with Lewis acids at the oxygen atom, the carbon atom, and at both atoms, respectively. In addition to the results reported, 2 is assumed to act as a chelating ligand with formation of a four-membered MCPO ring; however, no such compound could be isolated so far. Those compounds would have a constrained geometry and may act as catalysts for olefin polymerization $[25]$.

$$
\left[\mathrm{Ph}_{3} \mathrm{PCP}(\mathrm{O}) \mathrm{Ph}_{2}\right]^{-} \leftarrow \mathrm{Ph}_{3} \mathrm{PCHP}(\mathrm{O}) \mathrm{Ph}_{2} \quad \rightarrow \quad\left[\mathrm{Ph}_{3} \mathrm{PCH}_{2} \mathrm{P}(\mathrm{O}) \mathrm{Ph}_{2}\right]^{+}
$$

In addition, the proton at the carbon atom of $\mathbf{2}$ may also be replaced with strong Lewis bases to produce a double ylide-like anion (equation 2 left side) such as in complexes with the dianion $\left[\mathrm{Ph}_{2}(\mathrm{E}) \mathrm{P}-\mathrm{C}-\mathrm{P}(\mathrm{E}) \mathrm{Ph}_{2}\right]^{2-}$ $(E=N R, S)[26]$, but as yet, the acidity of this proton and the assumed amphoteric character of $\mathbf{2}$ is still unexplored. Further studies on the chemistry of $\mathbf{2}$ are currently in progress.

\section{Experimental Details}

All operations were carried out under an argon atmosphere in dried and degassed solvents using Schlenk techniques. The solvents were thoroughly dried and freshly distilled prior to use. The IR spectra were run on a Nicolet 510 spectrometer in Nujol mull. For the ${ }^{31} \mathrm{P}$ NMR spectra we used the instrument Bruker AC 200. Elemental analyses were performed by the analytical service of the Fachbereich Chemie at the Philipps Universität Marburg (Germany). The carbodiphosphorane $\mathrm{C}\left(\mathrm{PPh}_{3}\right)_{2}(\mathbf{1})$ was prepared according to a 
modified literature procedure [27]. $\left[\mathrm{BF}_{3}\left(\mathrm{OEt}_{2}\right)\right]$ was commercially obtained and used without further purification. $\mathrm{BI}_{3}$ was obtained according to the procedure described in [28].

$\mathbf{P h}_{\mathbf{3}} \mathbf{P C H P}(\mathbf{O}) \mathbf{P h}_{2}$ (2). A suspension of $2.3 \mathrm{~g}$ of $\mathbf{1}(4.3 \mathrm{mmol})$ in about $40 \mathrm{ml}$ toluene was stirred in a $100 \mathrm{ml}$ flask. The neck was closed by glass wool to allow a slow admission of moist air. After about $2 \mathrm{~h}$ the yellow color of $\mathbf{1}$ had disappeared and a colorless suspension was obtained. The solution was filtered from small amounts of an insoluble material. From the clear solution 1 could be precipitated as colorless crystals by layering with $n$-pentane. Yield $1.9 \mathrm{~g}$ (4.0 mmol, 95\% yield). ${ }^{31} \mathrm{P} \mathrm{NMR}\left(\mathrm{CH}_{2} \mathrm{Cl}_{2}, 200 \mathrm{MHz}, 298 \mathrm{~K}\right): 25.8$ (d, PO), $\left.19.2\left(\mathrm{~d}, \mathrm{PPh}_{3}\right) \mathrm{ppm},{ }^{2} \mathrm{~J}(\mathrm{P}, \mathrm{P})=19.7 \mathrm{~Hz}, \Delta=6.66 \mathrm{ppm}\right)$; similar values were obtained in $\mathrm{CHCl}_{3}(25.3$, $\left.18.6 \mathrm{ppm},{ }^{2} \mathrm{~J}(\mathrm{P}, \mathrm{P})=\mathrm{Hz}, \Delta=7.39 \mathrm{ppm}\right), \operatorname{THF}\left(26.7,21.5 \mathrm{ppm},{ }^{2} \mathrm{~J}(\mathrm{P}, \mathrm{P})=\mathrm{Hz}, \Delta=4.15 \mathrm{ppm}\right), \mathrm{DMSO}(25.2$, $\left.19.0 \mathrm{ppm},{ }^{2} \mathrm{~J}(\mathrm{P}, \mathrm{P})=20.4 \mathrm{~Hz}, \Delta=6.15 \mathrm{ppm}\right)$, and toluene $\left(25.3,20.6 \mathrm{ppm},{ }^{2} \mathrm{~J}(\mathrm{P}, \mathrm{P})=19.7 \mathrm{~Hz}, \Delta=4.65 \mathrm{ppm}\right)$ solutions. Remarkable is the shift difference $\Delta$ between the two doublets in the respective solvents. IR (Nujol mull, $\mathrm{cm}^{-1}$ ): 1479 s, 1435 vs, 1306 w, 1198 s, 1184 sh, 1171 vs, 1165 s, 1150 s, 1113 vs, 1100 vs, 1069 m, 1028m, 995 sh, 984 s, 964 s, 806 w, 789 w, 764 m, 750 s, 743 s, 714 vs, 694 vs, 569 m, 536 vs, 518 s, $500 \mathrm{~s}, 444 \mathrm{w}$.

Formation of $\left[\mathbf{P h}_{3} \mathbf{P C H P}\left(\mathbf{O B F}_{3}\right) \mathbf{P h}_{2}\right]$ (5). A solution of $0.59 \mathrm{~g}$ of $\mathbf{1}(1.1 \mathrm{mmol})$ containing small amounts of 2 (identified by ${ }^{31} \mathrm{PNMR}$ spectroscopy) in $20 \mathrm{ml}$ of toluene was admitted to an atmosphere of gaseous $\mathrm{BF}_{3}$ for about 1 hour and the mixture was stirred mechanically. A colorless precipitate formed immediately. After several days of standing, colorless whiskers of $\mathbf{5}$ had grown from the filtered solution. ${ }^{31} \mathrm{P}$ NMR $\left(\mathrm{CH}_{2} \mathrm{Cl}_{2}, 200 \mathrm{MHz}, 298 \mathrm{~K}\right): 21.02,19.38 \mathrm{ppm},{ }^{2} \mathrm{~J}(\mathrm{P}, \mathrm{P})=12.71 \mathrm{~Hz} . \mathrm{IR}\left(\right.$ Nujol mull, $\left.\mathrm{cm}^{-1}\right): 1613 \mathrm{~m}, 1588 \mathrm{w}$, 1487 w, 1441 st, 1358 m, 1196 st, 1154 st, 1113 st, 997 m, 922 w, 903 w, 862 m, 883 st, 797 st, 739 st, 710 w, 685 st, 660 w, 579 m, 564 w, 507 m, 501 m, 488 m. $\mathrm{C}_{31} \mathrm{H}_{36} \mathrm{BF}_{3} \mathrm{OP}_{2}$, found C 67.4, H 5.1, calcd C 68.4, H 4.8\%. The main product, probably the adduct $\mathrm{F}_{3} \mathrm{~B} \leftarrow \mathbf{1}$, dissolves in DMSO, and the ${ }^{31} \mathrm{P}$ NMR shows a signal at $20.8 \mathrm{ppm}$ indicating the formation of the cation $\left(\mathrm{HC}\left\{\mathrm{PPh}_{3}\right\}_{2}\right)^{+}$via proton abstraction from the solvent. 
Similar behavior was observed with other polar solvents such as DCM, DCE, and THF, therefore the structure of the precipitate could not be identified as yet.

Formation of $\left[\mathbf{P h}_{\mathbf{3}} \mathbf{P C H} \mathbf{2} \mathbf{P}\left(\mathbf{O B F}_{\mathbf{3}}\right) \mathbf{P h}_{2}\right]\left[\mathbf{H O B}_{2} \mathbf{F}_{\mathbf{6}}\right](\mathbf{6})$. From $\mathbf{2}$ and $\left[\mathrm{BF}_{3}\left(\mathrm{OEt}_{2}\right)\right]: 0.1 \mathrm{ml}$ of $\left[\mathrm{BF}_{3}\left(\mathrm{OEt}_{2}\right)\right](0.8$ mmol) was layered in a Schlenk tube with $2 \mathrm{ml}$ of toluene. This mixture was layered with a solution of 0.05 $\mathrm{g}$ of $2(0.11 \mathrm{mmol})$ in ca $1 \mathrm{ml}$ of toluene and allowed to stand overnight. Colorless crystals of $\mathbf{6}$ separated.

${ }^{31} \mathrm{P}$ NMR $\left(\mathrm{CH}_{2} \mathrm{Cl}_{2}, 200 \mathrm{MHz}, 298 \mathrm{~K}\right): 45.63(\mathrm{~m}, \mathrm{PO}), 17.54\left(\mathrm{~d}, \mathrm{PPh}_{3}\right),{ }^{2} \mathrm{~J}(\mathrm{P}, \mathrm{P})=17.80 \mathrm{~Hz} . \mathrm{IR}$ (Nujol mull, $\left.\mathrm{cm}^{-1}\right): 2723 \mathrm{~m}$, br $(\mathrm{v}(\mathrm{OH})), 1589 \mathrm{w}, 1485, \mathrm{w}, 1439 \mathrm{~s}, 1406 \mathrm{w}, 1367 \mathrm{~m}, 1341 \mathrm{w}, 1173$ to $1117 \mathrm{vs}(\mathrm{v}(\mathrm{BF}))$, 1034 m, 999 m, 856 s, 847 s, 801 s, 781 s, 743 vs, 731 s, 689 s, 600 w, 579 w, 557 w, 505 m, 490 m. 6 was also obtained from 2 and $\mathrm{BF}_{3}$ : A solution of $0.20 \mathrm{~g}$ of $2(0.42 \mathrm{mmol})$ in about $20 \mathrm{ml}$ of toluene was contacted with a bulb containing gaseous $\mathrm{BF}_{3}$. After some days crystals of $\mathbf{6}$ formed at the surface of the solution. The precipitate was filtered and dried in vacuum. ${ }^{31} \mathrm{P} \mathrm{NMR}\left(\mathrm{CD}_{2} \mathrm{Cl}_{2}, 200 \mathrm{MHz}, 298 \mathrm{~K}\right)$ : 45.69 (m, PO), $17.55\left(\mathrm{~d}, \mathrm{PPh}_{3}\right),{ }^{2} \mathrm{~J}(\mathrm{P}, \mathrm{P})=17.80 \mathrm{~Hz}$. Another set of two doublets at 23.54 and $18.75 \mathrm{ppm}\left({ }^{2} \mathrm{~J}(\mathrm{P}, \mathrm{P})=\right.$ $13.99 \mathrm{~Hz}$ ) belongs to 5 .

Formation of $\left[\mathbf{P h}_{3} \mathbf{P C H}_{2} \mathbf{P}\left(\mathbf{O B I}_{3}\right) \mathbf{P h}_{2}\right]\left[\mathbf{B I}_{4}\right](\mathbf{7})$ and $\left(\mathbf{H}_{2} \mathbf{C}\{\mathbf{P P h}\}_{2}\right)\left[\mathbf{I}_{3}\right] \mathbf{I}$. Solutions of $0.24 \mathrm{~g}(0.45 \mathrm{mmol})$ of $\mathbf{1}$ and of $0.84 \mathrm{~g}$ (2.14 mmol) of $\mathrm{BI}_{3}$, each in about $10 \mathrm{ml}$ of toluene, were combined at room temperature. The resulting precipitate was filtered. In the filtrate small yellow crystals had formed after several days which turned out to be $7 \cdot \mathrm{C}_{7} \mathrm{H}_{8} \cdot{ }^{31} \mathrm{P}$ NMR $\left(\mathrm{CH}_{2} \mathrm{Cl}_{2}, 200 \mathrm{MHz}, 298 \mathrm{~K}\right): 54.55(\mathrm{~m}, \mathrm{PO}), 16.20\left(\mathrm{~d}, \mathrm{PPh}_{3}\right),{ }^{2} \mathrm{~J}(\mathrm{P}, \mathrm{P})=$ 16.35 Hz). IR (Nujol mull, cm ${ }^{-1}$ ): 1558 m, 1480 m, 1439 s, 1339 w, 1312 w, 1213 m, 1181 s, 1161 m, 1099 w, 1074 w, 1028 w, 997 w, 963 m, 745 m, 735 m, 721 s, 710 w, 696 m, 687 m, 648 w, 536 s, 509 s. Part of the precipitate was dissolved in $\mathrm{MeCN}$. After five days needle-like orange red crystals separated which turned out to be the salt $\left(\mathrm{H}_{2} \mathrm{C}\left\{\mathrm{PPh}_{3}\right\}_{2}\right)\left[\mathrm{I}_{3}\right] \mathrm{I} .{ }^{31} \mathrm{P} \mathrm{NMR}(\mathrm{MeCN}): 18.30 \mathrm{ppm}$.

$\left[\mathbf{P h}_{3} \mathbf{P C H P}\left(\mathrm{OSnCl}_{2}\right) \mathbf{P h}_{2}\right](\mathbf{8})$ : To a solution of $0.21 \mathrm{~g}$ of $\mathbf{2}(0.44 \mathrm{mmol})$ in about $4 \mathrm{ml}$ DCM $0.27 \mathrm{~g}$ of anhydrous $\mathrm{SnCl}_{2}(0.88 \mathrm{mmol})$ was added, and the mixture was treated for $30 \mathrm{~min}$ in an ultrasonic bath at room temperature. The resulting suspension was filtered from some insoluble material. The ${ }^{31} \mathrm{P}$ NMR Wiley- $28 \mathrm{CH}$ 
spectrum of the solution showed two doublets at 38.74, $18.18 \mathrm{ppm}\left({ }^{2} \mathrm{~J}(\mathrm{P}, \mathrm{P})=19.67 \mathrm{~Hz}\right)$. After about $24 \mathrm{~h}$ the signals had disappeared in favor of two new doublets at $22.96,21.33\left({ }^{2} \mathrm{~J}(\mathrm{P}, \mathrm{P})=12.52 \mathrm{~Hz}\right.$. Layering of the solution with $n$-pentane gave colorless crystals after about three days which turned out to be the addition compound 8; the product was filtered and dried in vacuum; the yield was not determined. ${ }^{31} \mathrm{P}$ NMR: 23.01 , 21.40 (d's, $\left.{ }^{2} \mathrm{~J}(\mathrm{P}, \mathrm{P})=14.3 \mathrm{~Hz}\right)$ in DCM and 23.32. $21.79\left(\mathrm{~d}\right.$ 's, $\left.{ }^{2} \mathrm{~J}(\mathrm{P}, \mathrm{P})=14.3 \mathrm{~Hz}\right)$ in DMSO. IR (Nujol mull, $\mathrm{cm}^{-1}$ ): $1481 \mathrm{~m}, 1447 \mathrm{~s}, 1194 \mathrm{~m}, 1181 \mathrm{~m}, 1157 \mathrm{w}, 1117 \mathrm{~s}, 1107 \mathrm{~s}, 1030 \mathrm{~s}, 1018 \mathrm{~s}, 997 \mathrm{~s}, 972 \mathrm{~s}, 806 \mathrm{~m}, 758$ m, 747 s, 737 s, 723 s, 718 m, 702 m, 692 s, 596 m, 527 s, 515 s, 494 m, 480 m, 467 w, 467 w, 434 w. $\mathrm{C}_{31} \mathrm{H}_{26} \mathrm{Cl}_{2} \mathrm{OP}_{2} \mathrm{Sn}$ (MW 666.07), found C 54.7, H 4.1, calcd C 55.90, H $3.94 \%$.

$\left[\mathbf{P h}_{3} \mathbf{P C H} \mathbf{H}_{2} \mathbf{P}(\mathbf{O}) \mathbf{P h}_{2}\right]_{2}\left[\mathbf{H g}_{2} \mathbf{I}_{6}\right](\mathbf{9})$ : To a solution of $0.07 \mathrm{~g}$ of $\mathbf{2}(0.15 \mathrm{mmol})$ in about $3 \mathrm{ml} \mathrm{THF} 0.09 \mathrm{~g}(0.2$ mmol) of $\mathrm{HgI}_{2}$ was added; a clear solution was obtained. The ${ }^{31} \mathrm{P}$ NMR spectrum of the solution showed two doublets at 21.79, $21.07 \mathrm{ppm}\left(\mathrm{d}\right.$ s,$\left.{ }^{2} \mathrm{~J}(\mathrm{P}, \mathrm{P})=12.51 \mathrm{~Hz}\right)$ along with two broad bands at 27.1 and $26.3 \mathrm{ppm}$. Layering of the solution with $n$-pentane gave colorless crystals overnight which turned out to be the salt 9. ${ }^{31}$ P NMR (DMSO, 300 MHz, 298 K): 23.34, 21.92 (d's, $\left.{ }^{2} \mathrm{~J}(\mathrm{P}, \mathrm{P})=14.3 \mathrm{~Hz}\right)$. IR (Nujol mull, $\mathrm{cm}^{-1}$ ): $1588 \mathrm{~m}$, 1484 m, 1437 s, 1375 m, 1334 m, 1185 s, 1118 s, 1071 m, 998 m, 799 s, 783 s, 743 m 743 s, 729 s, 712 s, 689 s, 556 m, 503 s, 484 m. $\mathrm{C}_{31} \mathrm{H}_{27} \mathrm{HgI}_{3} \mathrm{OP}_{2}$ (MW 1058.77), found C 35.05, H 2.63, calcd C 35.17, H 2.57 $\%$.

Crystallographic data for the structures have been deposited with the Cambridge Crystallographic Data Centre, 12 Union Road, Cambridge CB21EZ. Copies of the data can be obtained on quoting the depository numbers CCDC 757261 (2), CCDC 757262 (5), CCDC 757263 (6), CCDC 757264 (7·C $\left.7 \mathrm{H}_{8}\right), \mathrm{CCDC} 757265$ (8), and CCDC 757266 (9) (Fax: (+44)1223-336-033; E-mail: deposit@ccdc.cam.ac.uk).

Acknowledgement. We thank the Deutsche Forschungsgemeinschaft for financial support. W. P. is also grateful to the Max-Planck-Society, Munich, Germany, for supporting this research project.

\section{References}


[1] F. Ramirez, N. B. Desai, B. Hanson, N. McKelvie, J. Am. Chem. Soc. 1961, 83, 3539.

[2] Transition metal adducts: a) W. Petz, F. Weller, J. Uddin, G. Frenking, Organometallics 1999, 18, 619;

b) J. Sundermeyer, K. Weber, K. Peters, H. G. von Schnering, Organometallics 1994, 13, 2560; c) H.

Schmidbaur, C. E. Zybill, G. Müller, C. Krüger, Angew. Chem. 1983, 95, 753; Angew. Chem., Int. Ed. 1983, 22, 729. Main group adducts: a) H. Schmidbaur, C. E. Zybill, D. Neugebauer, Angew. Chem. 1982, 94, 321; Angew. Chem., Int. Ed. 1982, 21, 310; b) H. Schmidbaur, C. Zybill, D. Neugebauer, G. Müller, Z.

Naturforsch. 1985, 40b, 1293; c) Ref. 4; d) W. Petz, F. Weller, C. Kutschera, M. Heitbaum, G. Frenking, R. Tonner, B. Neumüller, Inorg. Chem. 2005, 44, 1263.

[3] W. C. Kaska, D. K. Mitchel, R. F. Reichelderfer, J. Organomet. Chem. 1973, 47, 391.

[4] W. Petz, C. Kutschera, B. Neumüller, Organometallics 2005, 24, 5038.

[5] S. J. Sabounchei, A. Dadrass, F. Akhlaghi, Z. B. Nojini, H. R. Khaasi, Polyhedron 2008, 27, 1963, and literature therein.

[6] S. Z. Goldberg, K. N. Raymond, Inorg. Chem. 1973, 12, 2923.

[7] a) W. Petz, C. Kutschera, S. Tschan, F. Weller, B. Neumüller, Z. Anorg. Allg. Chem. 2003, 629, 1235.

[8] E. Lindner, E. Lehner, H. Scheer, Chem. Ber. 1967, 100, 1331.

[9] S. Milicev, D. Hadzi, Inorg. Chim. Acta 1977, 21, 201.

[10] W. Petz, B. Neumüller, unpublished results

[11] W. Petz, F. Öxler, B. Neumüller, R. Tonner, G. Frenking, Eur. J. Inorg. Chem. 2009, 4507.

[12] G. E. Hardy, J. I. Zink, W. C. Kaska, J. C. Baldwin, J. Am. Chem. Soc. 1978, 100, 8002.

[13] W. Petz, B. Neumüller, G. Frenking, R. Tonner, Angew. Chem. 2006, 118, 8206; Angew. Chem. Int. Ed. Engl. 2006, 45, 8038 .

[14] a) G. Ruban, V. Zabel, Cryst. Struct. Commun. 1976, 5, 671; b) G. Bandoli, G. Bortolozzo, D. A.

Clemente, U. Croatto, C. Panaltoni, J. Chem. Soc. A, 1970, 2788.

[15] G. M. Sheldrick, SHELXS-97, Programm zur Lösung von Kristallstrukturen, Göttingen 1997. 
[16] A. Altomare, G. Cascarano, C. Giacovazzo, A. Guagliardi, M. C. Burla, G. Polidori, M. Camalli, Sir92, Rome, 1992.

[17] G. M. Sheldrick, SHELXL-97, Program for the refinement of Crystal Structures, University of Göttingen, Göttingen (Germany) 1997.

[18] N. Burford, R. E. v. H. Spence, A. Linden, T. S. Cameron, Acta Crystallogr., Sect. C: Cryst. Struct. Commun. 1990, 46, 92.

[19] N. Burford, B. W. Royan, R. E. v. H. Spence, T. S. Cameron, A. Linden, R. D. Rogers, J. Chem. Soc. Dalton Trans. 1990, 1521.

[20] N. Kuhn, M. Göhner, M. Steimann, Z. Anorg. Allg. Chem. 2003, 629, 595.

[21] G. Santiso-Quinones, I. Krossing, Z. Anorg. Allg. Chem. 2008, 634, 704.

[22] W. Petz, K. Köhler, P. Mörschel, B. Neumüller, Z. Anorg. Allg. Chem. 2005, 631, 1779.

[23] E. Hough, D. G. Nicholson, J. Chem. Soc. Dalton Trans. 1976, 1782.

[24] H. Kiriyama, K. Kitahama, O. Nakamura, R. Kiriyama, Bull. Chem. Soc. Jpn. 1973, 46, 1389.

[25] a) G. J. P. Britovsek, V. C. Gibson, D. F. Wass, Angew. Chem. 1999, 111, 448; Angew. Chem. Int. Ed. 1999, 38, 428; b) V. C. Gibson, S. K. Spitzmesser, Chem. Rev. 2003, 103, 283.

[26] a) T. Cantat, N. Mezailles, L. Ricard, Y. Jean, P. Le Floch, Angew. Chem. 2004, 116, 6542; Angew.

Chem. Int. Ed. 2004, 43, 6382; b) M. Fang, N. D. Jones, K, Friesen, G. Lin, M. J. Ferguson, R. McDonald, R. Lukowsky, R. G. Cavell, Organometallics 2009, 28, 1652 ; c) T. Cantat, L. Ricard, N . Mezailles, P. Le Floch, Organometallics 2006, 25, 6030 ; d) T. Cantat, F. Jaroschik, L. Ricard, P. Le Floch, F. Nief, N. Mezailles, Organometallics 2006, 25, 1329 ; e) Y. Smurnyy, C. Bibal, M. Pink, K. G. Caulton, Organometallics 2005, 24, 3849.

[27] R. Appel, F. Knoll, H. Schöler, H.-D. Wihler, Angew. Chem. 1976, 88, 779; Angew. Chem. Int. Ed. Engl. 1976, 15, 701. 
[28] G. Brauer (Hg), Handbuch der Präparativen Anorganischen Chemie, Band 2, Ferdinand Enke Verlag,

Stuttgart, 3. Auflage, 1978.

Received:................. 2010

Published on line: ......... 
Table 1. Crystal data and structure refinement details for the compounds $\mathbf{2 , 5}, \mathbf{6}$, and $\mathbf{7} \cdot \mathrm{C}_{7} \mathrm{H}_{8}, \mathbf{8}$, and $\mathbf{9}$.

\begin{tabular}{|c|c|c|c|c|c|c|}
\hline & 2 & 5 & 6 & 7. $\mathrm{C}_{7} \mathrm{H}_{8}$ & 8 & 9 \\
\hline Formula & $\mathrm{C}_{31} \mathrm{H}_{26} \mathrm{OP}_{2}$ & $\mathrm{C}_{31} \mathrm{H}_{26} \mathrm{BF}_{3} \mathrm{OP}_{2}$ & $\mathrm{C}_{31} \mathrm{H}_{28} \mathrm{~B}_{3} \mathrm{~F}_{9} \mathrm{O}_{2} \mathrm{P}_{2}$ & $\mathrm{C}_{38} \mathrm{H}_{35} \mathrm{~B}_{2} \mathrm{I}_{7} \mathrm{OP}_{2}$ & $\mathrm{C}_{31} \mathrm{H}_{26} \mathrm{Cl}_{2} \mathrm{OP}_{2} \mathrm{Sn}$ & $\mathrm{C}_{62} \mathrm{H}_{45} \mathrm{Hg}_{2} \mathrm{I}_{6} \mathrm{O}_{2} \mathrm{P}_{4}$ \\
\hline $\mathrm{Mw} / \mathrm{g} \cdot \mathrm{mol}^{-1}$ & 476.49 & 544.30 & 697.92 & 1479.56 & 666.05 & 2117.51 \\
\hline $\mathrm{a} / \mathrm{pm}$ & $1004.8(1)$ & $1151.7(2)$ & $988.6(2)$ & $1108.0(1)$ & $1496.9(2)$ & $1194.0(1)$ \\
\hline $\mathrm{b} / \mathrm{pm}$ & $1476.5(2)$ & $1392.1(2)$ & $1059.4(2)$ & $1476.5(2)$ & 2061.0(3) & 1094.2(1) \\
\hline $\mathrm{c} / \mathrm{pm}$ & $1832.9(3)$ & $1653.8(3)$ & $1722.5(2)$ & $1444.4(2)$ & $1825.0(2)$ & $2552.1(2)$ \\
\hline$\alpha /^{\circ}$ & $107.93(1)$ & 90 & $79.46(2)$ & 90 & 90 & 90 \\
\hline$\beta /{ }^{\circ}$ & $98.55(1)$ & $97.63(1)$ & $78.46(2)$ & $106.50(1)$ & 90 & $100.36(1)$ \\
\hline$\gamma /{ }^{\circ}$ & $101.09(1)$ & 90 & $65.68(2)$ & 90 & 90 & 90 \\
\hline Crystal size/mm & $0.32 \times 0.14 \times 0.08$ & $0.17 \times 0.17 \times 0.04$ & $0.14 \times 0.06 \times 0.05$ & $0.24 \times 0.09 \times 0.05$ & $0.13 \times 0.12 \times 0.04$ & $0.18 \times 0.11 \times 0.09$ \\
\hline Volume $/ \mathrm{pm}^{3} \cdot 10^{6}$ & $2475.2(6)$ & $2628.0(8)$ & $1600.5(5)$ & $2265.7(5)$ & $5630(1)$ & $3279.9(5)$ \\
\hline Z & 4 & 4 & 2 & 2 & 8 & 2 \\
\hline $\mathrm{d}_{\text {calc }} / \mathrm{g} \cdot \mathrm{cm}^{-3}$ & 1.279 & 1.376 & 1.448 & 2.169 & 1.571 & 2.144 \\
\hline Crystal system & triclinic & monoclinic & triclinic & monoclinic & orthorhombic & monoclinic \\
\hline
\end{tabular}




\begin{tabular}{|c|c|c|c|c|c|c|}
\hline Space group & Pī (No. 2) & $\mathrm{P} 2_{1} / \mathrm{n}$ (No. 14) & $\mathrm{P} \overline{1}$ (No. 2) & $\mathrm{P} 2_{1}$ (No. 4) & Pbca (No. 61) & $\mathrm{P} 2{ }_{1} / \mathrm{n}$ (No. 14) \\
\hline Diffractometer & IPDS I (Stoe) & IPDS II (Stoe) & IPDS I (Stoe) & IPDS II (Stoe) & IPDS II (Stoe) & IPDS I (Stoe) \\
\hline Radiation & Mo-K ${ }_{\alpha}$ & Mo-K ${ }_{\alpha}$ & Mo-K ${ }_{\alpha}$ & Mo-K ${ }_{\alpha}$ & Mo-K ${ }_{\alpha}$ & Mo-K ${ }_{\alpha}$ \\
\hline Temperature/K & 193 & 100 & 193 & 173 & 100 & 193 \\
\hline$\mu / \mathrm{cm}^{-1}$ & 2.1 & 2.1 & 2.2 & 48.9 & 12.35 & 76.36 \\
\hline $2 \theta_{\max }{ }^{\circ}$ & 52.34 & 52.10 & 55.22 & 52.12 & 52.10 & 52.42 \\
\hline \multirow[t]{3}{*}{ Index range } & $-12 \leq \mathrm{h} \leq 12$ & $-14 \leq \mathrm{h} \leq 14$ & $-12 \leq \mathrm{h} \leq 12$ & $-13 \leq \mathrm{h} \leq 13$ & $-15 \leq \mathrm{h} \leq 18$ & $-14 \leq \mathrm{h} \leq 12$ \\
\hline & $-17 \leq \mathrm{k} \leq 17$ & $-17 \leq \mathrm{k} \leq 17$ & $-13 \leq \mathrm{k} \leq 13$ & $-17 \leq \mathrm{k} \leq 18$ & $-25 \leq \mathrm{k} \leq 25$ & $-13 \leq \mathrm{k} \leq 13$ \\
\hline & $-22 \leq 1 \leq 22$ & $-20 \leq 1 \leq 20$ & $-19 \leq 1 \leq 19$ & $-17 \leq 1 \leq 17$ & $-21 \leq 1 \leq 22$ & $-31 \leq 1 \leq 31$ \\
\hline Number of rflns & 23300 & 36597 & 15732 & 16018 & 34625 & 15021 \\
\hline collected & & & & & & \\
\hline Number of indep. & 9087 (0.0739) & $5138(0.1984)$ & $5835(0.0863)$ & $8017(0.065)$ & $5513(0.5512)$ & $6169(0.0578)$ \\
\hline rflns $\left(R_{\text {int }}\right)$ & & & & & & \\
\hline Number of & 4091 & 2389 & 2360 & 5058 & 1579 & 3410 \\
\hline
\end{tabular}




\begin{tabular}{|c|c|c|c|c|c|c|}
\hline with $\mathrm{F}_{0}>4 \sigma\left(\mathrm{F}_{0}\right)$ & & & & & & \\
\hline Parameters & 622 & 348 & 437 & 438 & 205 & 350 \\
\hline Absorption & numerical & numerical & numerical & numerical & numerical & numerical \\
\hline correction & & & & & & \\
\hline Structure solution & direct methods & direct methods & direct methods & direct methods & direct methods & direct methods \\
\hline & SHELXS-97 & SIR-92 [16] & SIR-92 [Error! & SHELXS-97 & SIR-92 [Error! & SHELXS-97 \\
\hline & {$[15]$} & & Bookmark not & [Error! & Bookmark not & [Error! \\
\hline & & & defined.] & Bookmark not & defined.] & Bookmark not \\
\hline & & & & defined.] & & defined.] \\
\hline Refinement & SHELXL-97 & SHELXL-97 & SHELXL-97 & SHELXL-97 & SHELXS-97 & SHELXL-97 \\
\hline against $\mathrm{F}^{2}$ & [17] & [Error! & [Error! & [Error! & [Error! & [Error! \\
\hline & & Bookmark not & Bookmark not & Bookmark not & Bookmark not & Bookmark not \\
\hline & & defined.] & defined.] & defined.] & defined.] & defined.] \\
\hline Flack-Parameter & - & - & - & $-0.05(3)$ & - & - \\
\hline $\mathrm{H}$ atoms & calculated & calculated & calculated & calculated & calculated & calculated \\
\hline & positions with & positions with & positions with & positions with & positions with & positions with \\
\hline & common & common & common & common & common & common \\
\hline
\end{tabular}




\begin{tabular}{|c|c|c|c|c|c|c|}
\hline & $\begin{array}{l}\text { displacement } \\
\text { parameter, } \mathrm{H}(1) \\
\text { was refined free }\end{array}$ & $\begin{array}{l}\text { displacement } \\
\text { parameter }\end{array}$ & $\begin{array}{l}\text { displacement } \\
\text { parameter, } H(1) \text {, } \\
H(2), H(3) \text { were } \\
\text { refined free }\end{array}$ & $\begin{array}{l}\text { displacement } \\
\text { parameter }\end{array}$ & $\begin{array}{l}\text { displacement } \\
\text { parameter }\end{array}$ & $\begin{array}{l}\text { displacement } \\
\text { parameter, } \mathrm{H}(1) \text {, } \\
\mathrm{H}(2) \text { were } \\
\text { refined free }\end{array}$ \\
\hline $\mathrm{R}_{1}$ & 0.0361 & 0.0608 & 0.0364 & 0.0411 & 0.0872 & 0.0367 \\
\hline $\mathrm{wR}_{2}$ (all data) & 0.0651 & 0.1299 & 0.0595 & 0.0611 & 0.2199 & 0.0834 \\
\hline $\begin{array}{l}\text { max. electron } \\
\text { density }\end{array}$ & 0.25 & 0.68 & 0.13 & 0.72 & 1.007 & 1.413 \\
\hline${ }^{\circ} \mathrm{left} / \mathrm{e} / \mathrm{pm}^{3} \cdot 10^{-6}$ & & & & & & \\
\hline
\end{tabular}


Table 2 Selected bond lengths/pm and angles $/{ }^{\circ}$ in one of the two independent molecules of 2

\begin{tabular}{|c|c|c|c|}
\hline $\mathrm{P}(1)-\mathrm{O}(1)$ & $148.9(2)$ & $\mathrm{P}(1)-\mathrm{C}(1)$ & $171.7(3)$ \\
\hline$P(1)-C(2)$ & 181.2(3) & $P(1)-C(8)$ & $182.2(3)$ \\
\hline$P(2)-C(1)$ & $168.8(3)$ & $P(2)-C(14)$ & $182.0(3)$ \\
\hline$P(2)-C(20)$ & $180.7(2)$ & $P(2)-C(26)$ & $181.9(3)$ \\
\hline $\mathrm{C}(1)-\mathrm{H}(1)$ & $0.85(3)$ & & \\
\hline $\mathrm{O}(1)-\mathrm{P}(1)-\mathrm{C}(1)$ & 114.1(1) & $\mathrm{O}(1)-\mathrm{P}(1)-\mathrm{C}(2)$ & 111.2(1) \\
\hline $\mathrm{O}(1)-\mathrm{P}(1)-\mathrm{C}(8)$ & 112.1(1) & $C(1)-P(1)-C(2)$ & $109.4(2)$ \\
\hline$C(1)-P(1)-C(8)$ & $107.8(1)$ & $C(2)-P(1)-C(8)$ & $101.4(1)$ \\
\hline$C(1)-P(2)-C(14)$ & $116.3(1)$ & $\mathrm{C}(1)-\mathrm{P}(2)-\mathrm{C}(20)$ & $105.3(2)$ \\
\hline$C(1)-P(2)-C(26)$ & $116.9(2)$ & $\mathrm{C}(14)-\mathrm{P}(2)-\mathrm{C}(20)$ & $106.9(1)$ \\
\hline$C(14)-P(2)-C(26)$ & $103.6(1)$ & $\mathrm{C}(20)-\mathrm{P}(2)-\mathrm{C}(26)$ & $107.2(1)$ \\
\hline $\mathrm{P}(1)-\mathrm{C}(1)-\mathrm{P}(2)$ & $127.5(2)$ & $\mathrm{P}(1)-\mathrm{C}(1)-\mathrm{H}(1)$ & $116(2)$ \\
\hline$P(2)-C(1)-H(1)$ & $116(2)$ & & \\
\hline
\end{tabular}


Table 3. Selected bond lengths/pm and angles $/{ }^{\circ}$ in $\mathbf{5}$.

\begin{tabular}{|c|c|c|c|}
\hline $\mathrm{P}(1)-\mathrm{O}(1)$ & $157.3(3)$ & $P(1)-C(1)$ & $168.1(4)$ \\
\hline$P(1)-C(2)$ & $179.7(4)$ & $P(1)-C(8)$ & $179.7(4)$ \\
\hline $\mathrm{P}(2)-\mathrm{C}(1)$ & $171.6(4)$ & $P(2)-C(14)$ & $180.3(4)$ \\
\hline$P(2)-C(20)$ & $180.7(4)$ & $P(2)-C(26)$ & $179.6(4)$ \\
\hline $\mathrm{F}(1)-\mathrm{B}(1)$ & $137.6(6)$ & $\mathrm{F}(2)-\mathrm{B}(1)$ & $140.2(5)$ \\
\hline $\mathrm{F}(3)-\mathrm{B}(1)$ & $135.9(5)$ & $\mathrm{O}(1)-\mathrm{B}(1)$ & $148.8(6)$ \\
\hline $\mathrm{C}(1)-\mathrm{H}(1)$ & $93(4)$ & & \\
\hline $\mathrm{O}(1)-\mathrm{P}(1)-\mathrm{C}(1)$ & $118.9(2)$ & $\mathrm{O}(1)-\mathrm{P}(1)-\mathrm{C}(2)$ & $108.9(2)$ \\
\hline $\mathrm{O}(1)-\mathrm{P}(1)-\mathrm{C}(8)$ & $101.4(2)$ & $C(1)-P(1)-C(2)$ & $107.3(2)$ \\
\hline$C(1)-P(1)-C(8)$ & $114.4(2)$ & $C(2)-P(1)-C(8)$ & $105.1(2)$ \\
\hline$C(1)-P(2)-C(14)$ & $113.5(2)$ & $C(1)-P(2)-C(20)$ & $110.7(2)$ \\
\hline$C(1)-P(2)-C(26)$ & $112.0(2)$ & $C(14)-P(2)-C(20)$ & $104.8(2)$ \\
\hline $\mathrm{C}(14)-\mathrm{P}(2)-\mathrm{C}(26)$ & $107.2(2)$ & $C(20)-P(2)-C(26)$ & $108.2(2)$ \\
\hline $\mathrm{P}(1)-\mathrm{O}(1)-\mathrm{B}(1)$ & $133.4(3)$ & $\mathrm{P}(1)-\mathrm{C}(1)-\mathrm{P}(2)$ & $131.7(3)$ \\
\hline$F(1)-B(1)-F(2)$ & 109.7(4) & $\mathrm{F}(1)-\mathrm{B}(1)-\mathrm{F}(3)$ & $111.1(4)$ \\
\hline $\mathrm{F}(1)-\mathrm{B}(1)-\mathrm{O}(1)$ & $110.0(4)$ & $F(2)-B(1)-F(3)$ & $110.2(4)$ \\
\hline $\mathrm{F}(2)-\mathrm{B}(1)-\mathrm{O}(1)$ & $106.9(3)$ & $\mathrm{F}(3)-\mathrm{B}(1)-\mathrm{O}(1)$ & $108.8(4)$ \\
\hline $\mathrm{P}(1)-\mathrm{C}(1)-\mathrm{H}(1)$ & $114(2)$ & $P(2)-C(1)-H(1)$ & $112(2)$ \\
\hline
\end{tabular}


Table 4. Selected bond lengths/pm and angles $/{ }^{\circ}$ in $\mathbf{6}$.

\begin{tabular}{|c|c|c|c|}
\hline $\mathrm{P}(1)-\mathrm{O}(1)$ & $152.9(2)$ & $P(1)-C(1)$ & $179.9(3)$ \\
\hline$P(1)-C(2)$ & $178.5(3)$ & $P(1)-C(8)$ & $177.3(3)$ \\
\hline $\mathrm{P}(2)-\mathrm{C}(1)$ & $181.3(3)$ & $P(2)-C(14)$ & $178.6(3)$ \\
\hline$P(2)-C(20)$ & $177.7(3)$ & $P(2)-C(26)$ & $178.2(3)$ \\
\hline $\mathrm{F}(1)-\mathrm{B}(1)$ & $138.8(4)$ & $\mathrm{F}(2)-\mathrm{B}(1)$ & $134.2(4)$ \\
\hline $\mathrm{F}(3)-\mathrm{B}(1)$ & $133.6(4)$ & $\mathrm{O}(1)-\mathrm{B}(1)$ & $154.2(4)$ \\
\hline $\mathrm{C}(1)-\mathrm{H}(1)$ & $87(3)$ & $\mathrm{C}(1)-\mathrm{H}(2)$ & $97(3)$ \\
\hline$F(4)-B(2)$ & $137.8(4)$ & $F(5)-B(2)$ & $137.8(4)$ \\
\hline$F(6)-B(2)$ & $135.3(4)$ & $\mathrm{F}(7)-\mathrm{B}(3)$ & $141.6(4)$ \\
\hline $\mathrm{F}(8)-\mathrm{B}(3)$ & $136.5(4)$ & $\mathrm{F}(9)-\mathrm{B}(3)$ & $137.1(4)$ \\
\hline $\mathrm{O}(2)-\mathrm{B}(2)$ & $151.9(4)$ & $\mathrm{O}(2)-\mathrm{B}(3)$ & $147.6(4)$ \\
\hline $\mathrm{O}(2)-\mathrm{H}(3)$ & $86(4)$ & & \\
\hline $\mathrm{O}(1)-\mathrm{P}(1)-\mathrm{C}(1)$ & $106.7(2)$ & $\mathrm{O}(1)-\mathrm{P}(1)-\mathrm{C}(2)$ & $111.2(1)$ \\
\hline $\mathrm{O}(1)-\mathrm{P}(1)-\mathrm{C}(8)$ & $111.6(1)$ & $C(1)-P(1)-C(2)$ & $108.5(2)$ \\
\hline$C(1)-P(1)-C(8)$ & $106.5(2)$ & $C(1)-P(2)-C(26)$ & $106.2(2)$ \\
\hline$C(1)-P(2)-C(14)$ & $109.6(2)$ & $C(1)-P(2)-C(20)$ & $113.6(2)$ \\
\hline $\mathrm{P}(1)-\mathrm{O}(1)-\mathrm{B}(1)$ & $133.4(2)$ & $P(1)-C(1)-P(2)$ & $119.9(2)$ \\
\hline$F(1)-B(1)-F(2)$ & $110.4(3)$ & $\mathrm{F}(1)-\mathrm{B}(1)-\mathrm{F}(3)$ & $110.8(4)$ \\
\hline $\mathrm{F}(1)-\mathrm{B}(1)-\mathrm{O}(1)$ & $106.9(3)$ & $F(2)-B(1)-F(3)$ & $114.9(4)$ \\
\hline $\mathrm{F}(2)-\mathrm{B}(1)-\mathrm{O}(1)$ & $107.4(4)$ & $\mathrm{F}(3)-\mathrm{B}(1)-\mathrm{O}(1)$ & $105.7(3)$ \\
\hline$P(1)-C(1)-H(1)$ & $110(2)$ & $P(1)-C(1)-H(2)$ & $107(2)$ \\
\hline
\end{tabular}




\begin{tabular}{llll}
\hline $\mathrm{P}(2)-\mathrm{C}(1)-\mathrm{H}(1)$ & $107(2)$ & $\mathrm{P}(2)-\mathrm{C}(1)-\mathrm{H}(2)$ & $111(2)$ \\
$\mathrm{H}(1)-\mathrm{C}(1)-\mathrm{H}(2)$ & $100(3)$ & $\mathrm{B}(2)-\mathrm{O}(1)-\mathrm{B}(3)$ & $127.6(3)$ \\
$\mathrm{F}(4)-\mathrm{B}(2)-\mathrm{F}(5)$ & $111.7(3)$ & $\mathrm{F}(4)-\mathrm{B}(2)-\mathrm{F}(6)$ & $110.8(3)$ \\
$\mathrm{F}(4)-\mathrm{B}(2)-\mathrm{O}(2)$ & $107.3(3)$ & $\mathrm{F}(5)-\mathrm{B}(2)-\mathrm{F}(6)$ & $111.4(4)$ \\
$\mathrm{F}(5)-\mathrm{B}(2)-\mathrm{O}(2)$ & $105.3(3)$ & $\mathrm{F}(6)-\mathrm{B}(2)-\mathrm{O}(2)$ & $110.1(3)$ \\
$\mathrm{F}(7)-\mathrm{B}(3)-\mathrm{F}(8)$ & $109.9(3)$ & $\mathrm{F}(7)-\mathrm{B}(3)-\mathrm{F}(9)$ & $108.0(3)$ \\
$\mathrm{F}(7)-\mathrm{B}(3)-\mathrm{O}(2)$ & $108.8(3)$ & $\mathrm{F}(8)-\mathrm{B}(3)-\mathrm{F}(9)$ & $112.2(4)$ \\
$\mathrm{F}(8)-\mathrm{B}(3)-\mathrm{O}(2)$ & $109.5(3)$ & $\mathrm{F}(9)-\mathrm{B}(3)-\mathrm{O}(2)$ & $108.2(3)$ \\
$\mathrm{B}(2)-\mathrm{O}(2)-\mathrm{H}(3)$ & $102(2)$ & $\mathrm{B}(3)-\mathrm{O}(2)-\mathrm{H}(3)$ & $124(2)$
\end{tabular}


Table 5. Selected bond lengths/pm and angles $/{ }^{\circ}$ in $\mathbf{7} \cdot \mathrm{C}_{7} \mathrm{H}_{8}$.

\begin{tabular}{|c|c|c|c|}
\hline $\mathrm{I}(1)-\mathrm{B}(1)$ & $221(1)$ & $\mathrm{I}(2)-\mathrm{B}(1)$ & $222(1)$ \\
\hline $\mathrm{I}(3)-\mathrm{B}(1)$ & $229(1)$ & $P(1)-C(1)$ & $180(1)$ \\
\hline$P(1)-C(2)$ & $177.0(9)$ & $P(1)-C(8)$ & $179(1)$ \\
\hline$P(1)-C(14)$ & $176(1)$ & $\mathrm{P}(2)-\mathrm{O}(1)$ & $154.5(1)$ \\
\hline$P(2)-C(1)$ & $180.4(8)$ & $P(2)-C(20)$ & $175(1)$ \\
\hline$P(2)-C(26)$ & $178(1)$ & $\mathrm{O}(1)-\mathrm{B}(1)$ & $148(1)$ \\
\hline $\mathrm{C}(1)-\mathrm{H}(1)$ & 99 & $C(1)-H(2)$ & 99 \\
\hline $\mathrm{I}(4)-\mathrm{B}(2)$ & $228(1)$ & $\mathrm{I}(5)-\mathrm{B}(2)$ & $222(2)$ \\
\hline $\mathrm{I}(6)-\mathrm{B}(2)$ & $224(2)$ & $\mathrm{I}(7)-\mathrm{B}(2)$ & $222(1)$ \\
\hline$C(1)-P(1)-C(2)$ & $107.1(5)$ & $C(1)-P(1)-C(8)$ & $110.9(5)$ \\
\hline$C(1)-P(1)-C(14)$ & $110.3(5)$ & $\mathrm{O}(1)-\mathrm{P}(2)-\mathrm{C}(1)$ & $104.7(4)$ \\
\hline $\mathrm{O}(1)-\mathrm{P}(2)-\mathrm{C}(20)$ & $116.3(4)$ & $\mathrm{O}(1)-\mathrm{P}(2)-\mathrm{C}(26)$ & $111.0(5)$ \\
\hline$C(1)-P(2)-C(20)$ & $106.8(5)$ & $C(1)-P(2)-C(26)$ & $108.0(4)$ \\
\hline $\mathrm{P}(2)-\mathrm{O}(1)-\mathrm{B}(1)$ & $139.0(7)$ & $\mathrm{P}(1)-\mathrm{C}(1)-\mathrm{P}(2)$ & $120.9(6)$ \\
\hline $\mathrm{I}(1)-\mathrm{B}(1)-\mathrm{I}(2)$ & $109.6(4)$ & $\mathrm{I}(1)-\mathrm{B}(1)-\mathrm{I}(3)$ & $109.9(5)$ \\
\hline $\mathrm{I}(1)-\mathrm{B}(1)-\mathrm{O}(1)$ & $107.3(7)$ & $\mathrm{I}(2)-\mathrm{B}(1)-\mathrm{O}(1)$ & $112.9(7)$ \\
\hline $\mathrm{I}(3)-\mathrm{B}(1)-\mathrm{O}(1)$ & $108.1(6)$ & $\mathrm{P}(1)-\mathrm{C}(1)-\mathrm{H}(1)$ & 107 \\
\hline$P(1)-C(1)-H(2)$ & 107 & $\mathrm{P}(2)-\mathrm{C}(1)-\mathrm{H}(1)$ & 107 \\
\hline$P(2)-C(1)-H(2)$ & 107 & $\mathrm{H}(1)-\mathrm{C}(1)-\mathrm{H}(2)$ & 106 \\
\hline
\end{tabular}


Table 6. Selected bond lengths/pm and angles $/{ }^{\circ}$ in $\mathbf{8}$.

\begin{tabular}{|c|c|c|c|}
\hline $\mathrm{P}(1)-\mathrm{O}(1)$ & $156(1)$ & $\mathrm{P}(1)-\mathrm{C}(1)$ & $168(2)$ \\
\hline$P(1)-C(2)$ & $182.0(3)$ & $P(1)-C(8)$ & 183 \\
\hline $\mathrm{P}(2)-\mathrm{C}(1)$ & $172(2)$ & $P(2)-C(14)$ & 181 \\
\hline$P(2)-C(20)$ & 183 & $P(2)-C(26)$ & 180 \\
\hline $\mathrm{O}(1)-\mathrm{Sn}(1)$ & $212(1)$ & $\mathrm{Cl}(1)-\operatorname{Sn}(1)$ & $250.0(5)$ \\
\hline $\mathrm{Cl}(2)-\mathrm{Sn}(1)$ & $247.0(5)$ & $C(1)-H(11)$ & 95 \\
\hline $\mathrm{O}(1)-\mathrm{Sn}(1)-\mathrm{Cl}(2)$ & $90.9(3)$ & $\mathrm{O}(1)-\mathrm{Sn}(1)-\mathrm{Cl}(1)$ & $88.3(3)$ \\
\hline $\mathrm{Cl}(2)-\mathrm{Sn}(1)-\mathrm{Cl}(1)$ & $92.5(2)$ & $\mathrm{P}(1)-\mathrm{C}(1)-\mathrm{P}(2)$ & $128(1)$ \\
\hline $\mathrm{P}(1)-\mathrm{C}(1)-\mathrm{H}(11)$ & 115.9 & $\mathrm{P}(2)-\mathrm{C}(1)-\mathrm{H}(11)$ & 115.9 \\
\hline $\mathrm{P}(1)-\mathrm{O}(1)-\mathrm{Sn}(1)$ & $138.1(6)$ & $\mathrm{O}(1)-\mathrm{P}(1)-\mathrm{C}(1)$ & $119.2(7)$ \\
\hline $\mathrm{O}(1)-\mathrm{P}(1)-\mathrm{C}(2)$ & $105.6(4)$ & $C(1)-P(1)-C(2)$ & $108.1(5)$ \\
\hline $\mathrm{O}(1)-\mathrm{P}(1)-\mathrm{C}(8)$ & $105.4(4)$ & $C(1)-P(1)-C(8)$ & $111.1(5)$ \\
\hline$C(2)-P(1)-C(8)$ & 106.7 & $C(1)-P(2)-C(14)$ & $115.5(5)$ \\
\hline$C(1)-P(2)-C(26)$ & $108.8(5)$ & $C(26)-P(2)-C(14)$ & 105.5 \\
\hline$C(1)-P(2)-C(20)$ & $112.0(6)$ & $C(26)-P(2)-C(20)$ & 108.6 \\
\hline$C(14)-P(2)-C(20)$ & 106.0 & & \\
\hline
\end{tabular}


Table 7. Selected bond lengths/pm and angles/ ${ }^{\circ}$ in $\mathbf{9}$.

\begin{tabular}{|c|c|c|c|}
\hline $\operatorname{Hg}(1)-\mathrm{I}(3)$ & $267.01(8)$ & $\operatorname{Hg}(1)-\mathrm{I}(2)$ & $270.35(6)$ \\
\hline $\mathrm{Hg}(1)-\mathrm{I}(1) \mathrm{A}$ & $280.51(7)$ & $\operatorname{Hg}(1)-\mathrm{I}(1)$ & $300.77(8)$ \\
\hline $\mathrm{P}(1)-\mathrm{O}(1)$ & $147.9(6)$ & $\mathrm{P}(1)-\mathrm{C}(1)$ & $182.2(8)$ \\
\hline$P(1)-C(2)$ & $179.2(8)$ & $P(1)-C(8)$ & $180.6(7)$ \\
\hline $\mathrm{P}(2)-\mathrm{C}(1)$ & 179.7(8) & $P(2)-C(14)$ & $178.5(7)$ \\
\hline$P(2)-C(20)$ & 179.1(9) & $\mathrm{P}(2)-\mathrm{C}(26)$ & $179.5(8)$ \\
\hline $\mathrm{C}(1)-\mathrm{H}(1)$ & $101(8)$ & $C(1)-H(2)$ & $93(9)$ \\
\hline $\mathrm{I}(3)-\mathrm{Hg}(1)-\mathrm{I}(2)$ & $120.81(2)$ & $\mathrm{I}(3)-\mathrm{Hg}(1)-\mathrm{I}(1) \mathrm{A}$ & $118.50(3)$ \\
\hline $\mathrm{I}(2)-\mathrm{Hg}(1)-\mathrm{I}(1) \mathrm{A}$ & $108.32(2)$ & $\mathrm{I}(3)-\mathrm{Hg}(1)-\mathrm{I}(1)$ & $107.94(2)$ \\
\hline $\mathrm{I}(2)-\mathrm{Hg}(1)-\mathrm{I}(1)$ & $102.01(2)$ & $\mathrm{I}(1) \mathrm{A}-\mathrm{Hg}(1)-\mathrm{I}(1)$ & $94.52(2)$ \\
\hline $\operatorname{Hg}(1) \mathrm{A}-\mathrm{I}(1)-\operatorname{Hg}(1)$ & $85.48(2)$ & $P(1)-C(1)-P(2)$ & $118.2(4)$ \\
\hline$P(2)-C(1)-H(1)$ & $102(6)$ & $\mathrm{P}(1)-\mathrm{C}(1)-\mathrm{H}(1)$ & $115(5)$ \\
\hline$P(2)-C(1)-H(2)$ & $116(6)$ & $\mathrm{P}(1)-\mathrm{C}(1)-\mathrm{H}(2)$ & $105(6)$ \\
\hline $\mathrm{H}(1)-\mathrm{C}(1)-\mathrm{H}(2)$ & 101(7) & $\mathrm{O}(1)-\mathrm{P}(1)-\mathrm{C}(2)$ & $112.3(3)$ \\
\hline $\mathrm{O}(1)-\mathrm{P}(1)-\mathrm{C}(8)$ & $113.0(3)$ & $C(2)-P(1)-C(8)$ & $109.6(4)$ \\
\hline $\mathrm{O}(1)-\mathrm{P}(1)-\mathrm{C}(1)$ & $112.5(4)$ & $C(2)-P(1)-C(1)$ & $102.3(3)$ \\
\hline$C(8)-P(1)-C(1)$ & $106.4(4)$ & $C(14)-P(2)-C(1)$ & 110.1(4) \\
\hline$C(20)-P(2)-C(1)$ & $108.3(4)$ & $C(26)-P(2)-C(1)$ & $112.0(4)$ \\
\hline
\end{tabular}




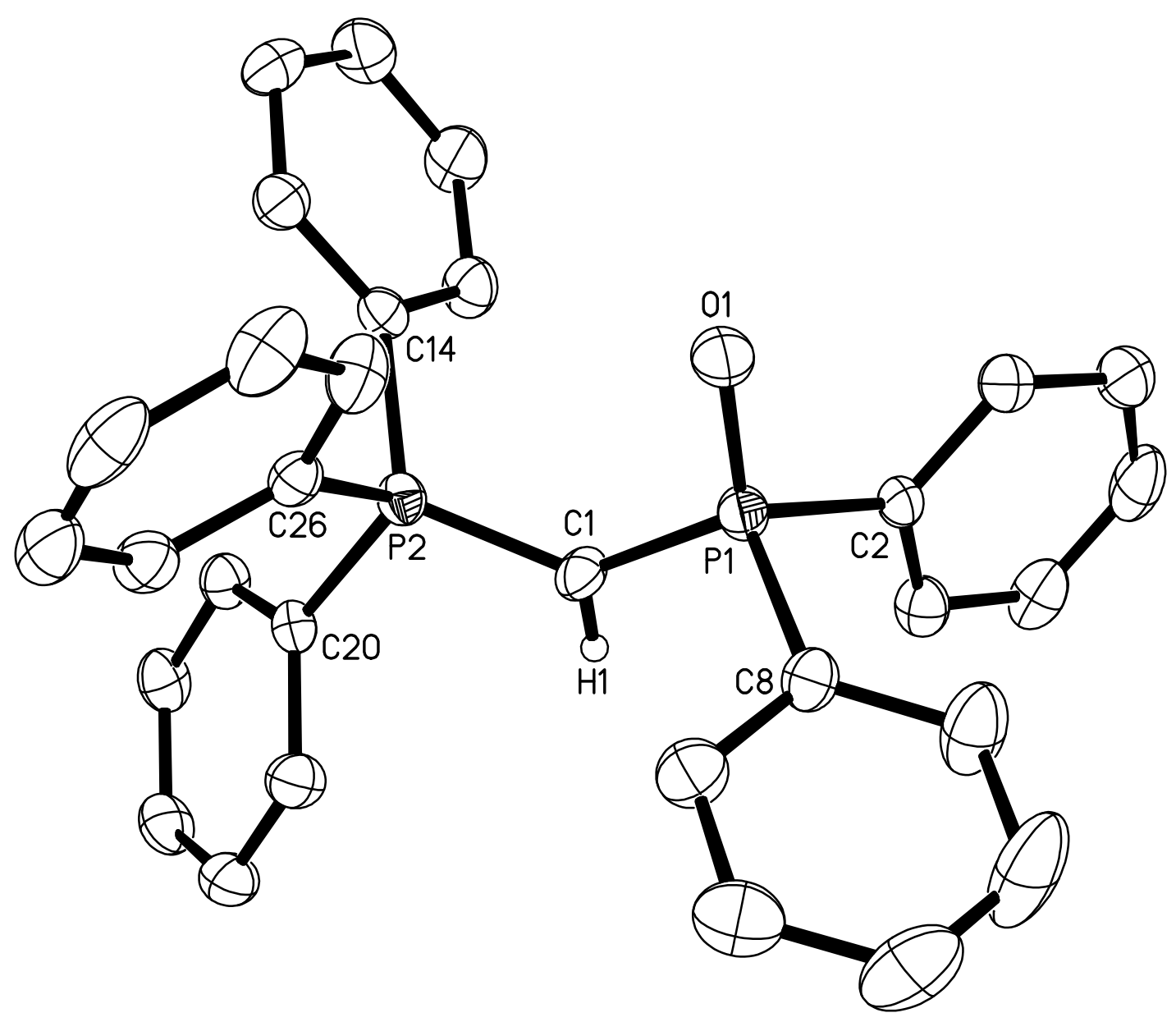

Figure 1. Molecular structure of $\mathrm{Ph}_{3} \mathrm{PCHP}(\mathrm{O}) \mathrm{Ph}_{2}$ (2) with thermal ellipsoids at $40 \%$ probability, the hydrogen atoms are omitted for clarity. 


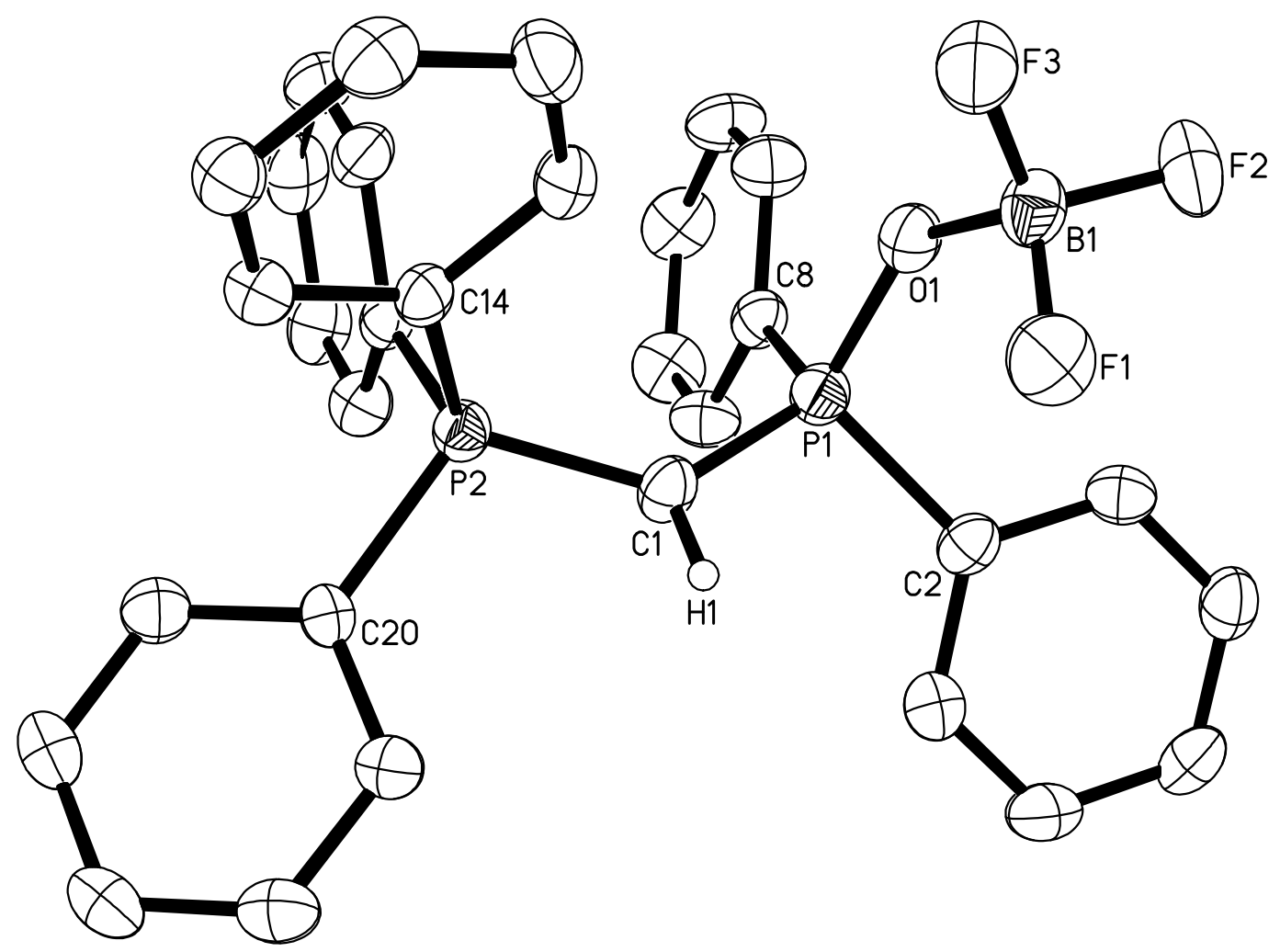

Figure 2. Molecular structure of $\mathrm{Ph}_{3} \mathrm{PCHP}\left(\mathrm{OBF}_{3}\right) \mathrm{Ph}_{2}(5)$ with thermal ellipsoids at $40 \%$ probability, the hydrogen atoms are omitted for clarity. 


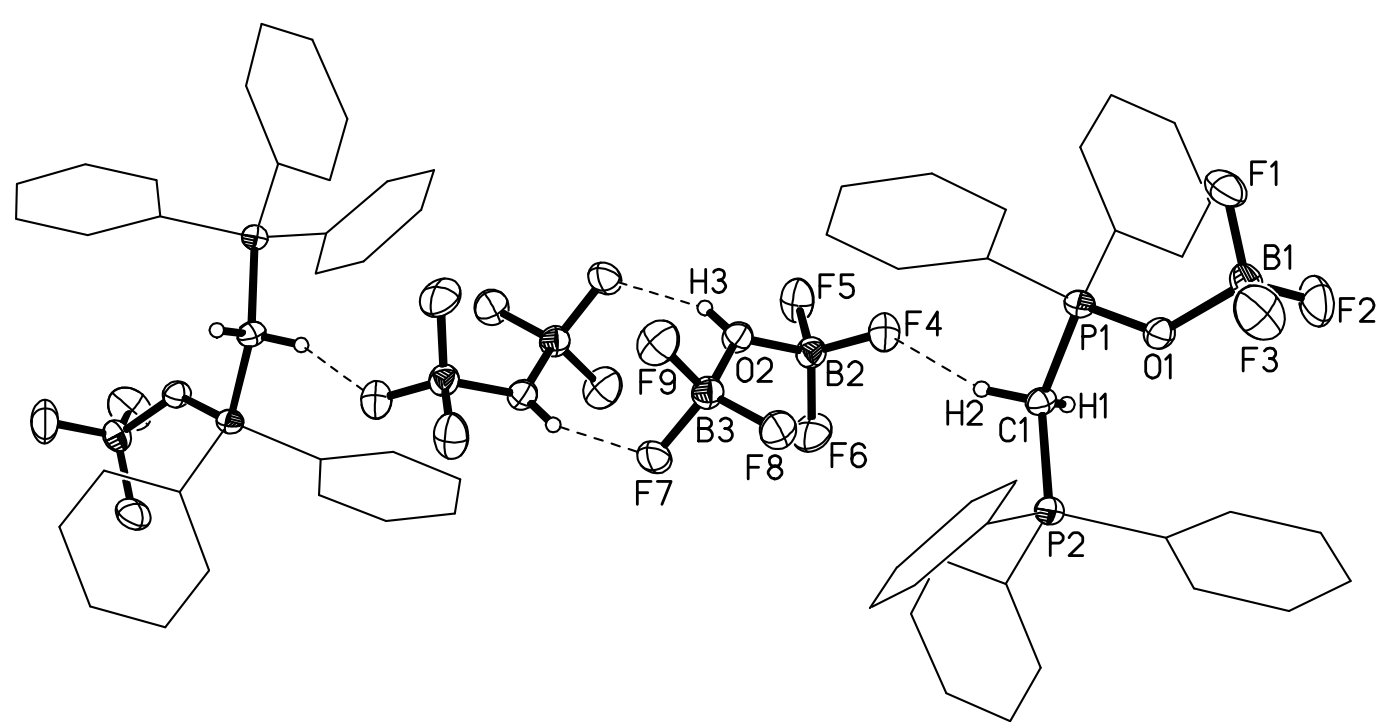

Figure 3. Molecular structure of $\left[\mathrm{Ph}_{3} \mathrm{PCH}_{2} \mathrm{P}\left(\mathrm{OBF}_{3}\right) \mathrm{Ph}_{2}\right]\left[(\mu-\mathrm{OH}) \mathrm{B}_{2} \mathrm{~F}_{6}\right](6)$. The two cations and two anions are connected through H-bonds to a centrosymmetrical dimer. The ellipsoids are drawn at a $40 \%$ probability level; the phenyl groups are represented as thin lines omitting the $\mathrm{H}$ atoms for clarity. 


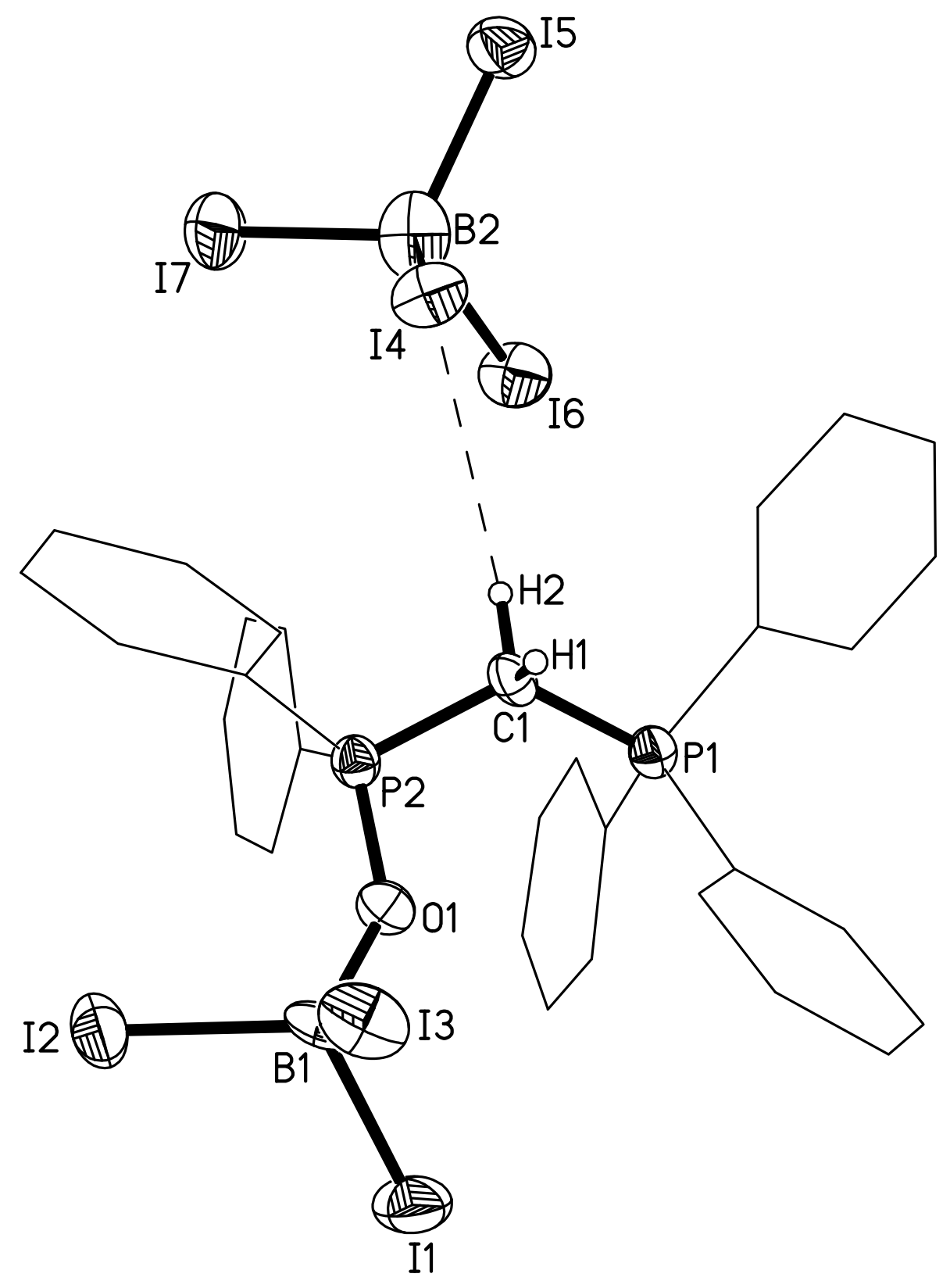

Figure 4. Molecular structure of $\left[\mathrm{Ph}_{3} \mathrm{PCH}_{2} \mathrm{P}\left(\mathrm{OBI}_{3}\right) \mathrm{Ph}_{2}\right]\left[\mathrm{BI}_{4}\right]$ (7). The ellipsoids are drawn at a $40 \%$ probability level; the phenyl groups are represented as thin lines omitting the $\mathrm{H}$ atoms for clarity. 


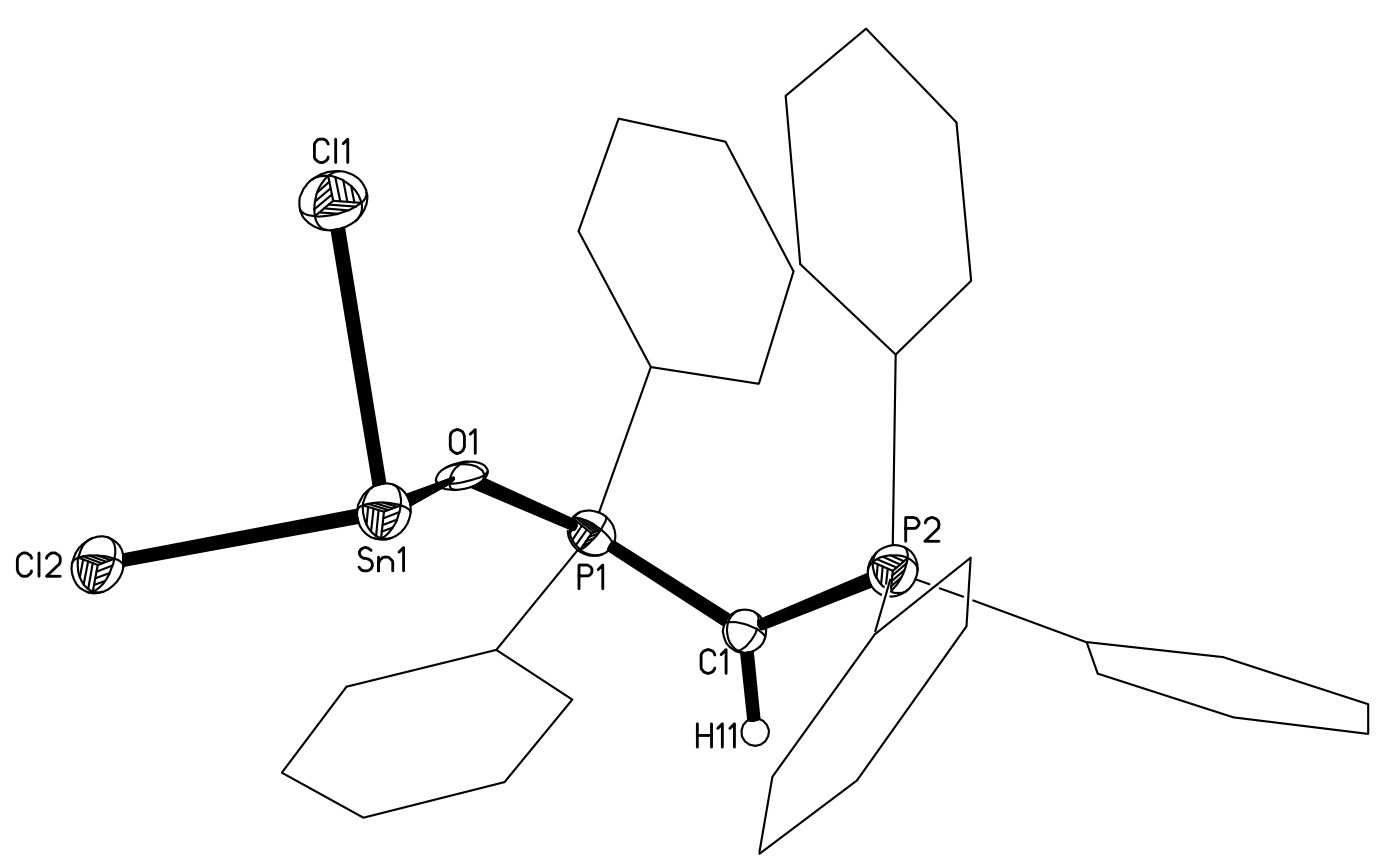

Figure 5. Molecular structure of $\left[\mathrm{Ph}_{3} \mathrm{PCHP}\left(\mathrm{OSnCl}_{2}\right) \mathrm{Ph}_{2}\right](\mathbf{8})$. The ellipsoids are drawn at a $40 \%$ probability level; the phenyl rings are refined as rigid groups and are represented as thin lines omitting the $\mathrm{H}$ atoms for clarity. The ellipsoids are drawn at a $40 \%$ probability level; the phenyl groups are represented as thin lines omitting the $\mathrm{H}$ atoms for clarity. 


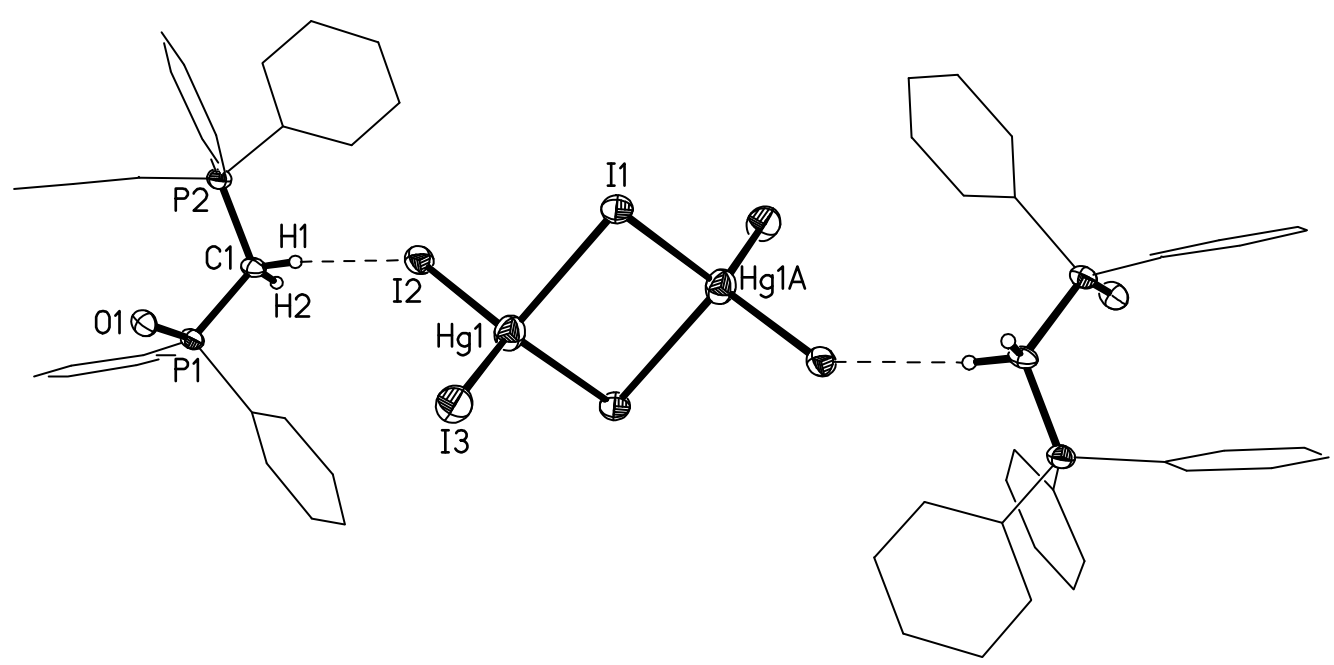

Figure 6. Molecular structure of $\left[\mathrm{Ph}_{3} \mathrm{PCH}_{2} \mathrm{P}(\mathrm{O}) \mathrm{Ph}_{2}\right]_{2}\left[\mathrm{Hg}_{2} \mathrm{I}_{6}\right](9)$. The ellipsoids are drawn at a $40 \%$ probability level; the phenyl groups are represented as thin lines omitting the $\mathrm{H}$ atoms for clarity. 


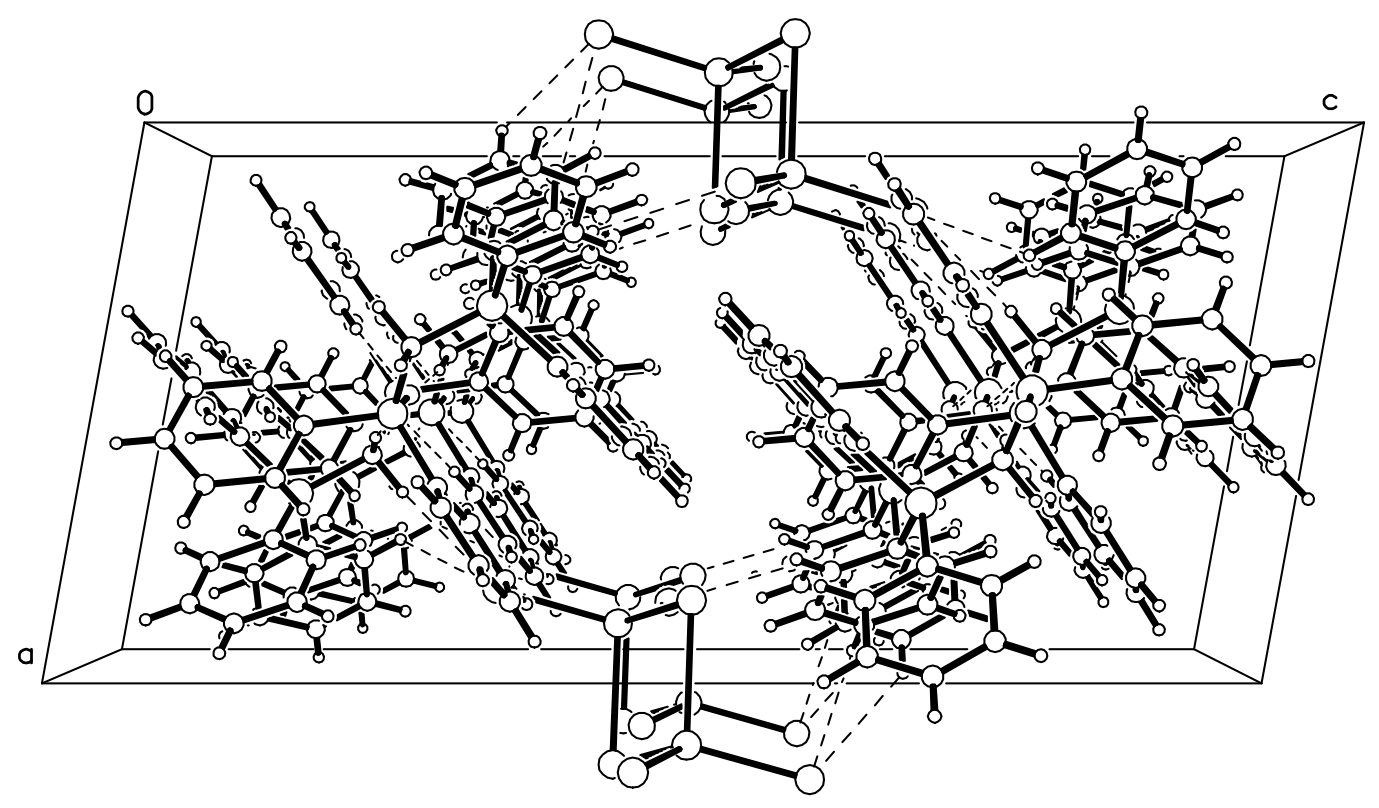

Figure 7. Crystal packing diagram of compound 9 viewed along the $b$ axis; hydrogen bonds are indicated by dashed lines. 